\title{
A reconfiguração do sindicalismo \\ brasileiro nos anos 2000: \\ as bases sociais e o perfil \\ político-ideológico da Conlutas
}

\begin{tabular}{c}
\hline \hline Patrícia Vieira Trópia \\
Departamento de Ciências Sociais \\
Universidade Federal de Uberlândia \\
Andréia Galvão \\
Departamento de Ciência Política \\
Universidade Estadual de Campinas \\
Paula Marcelino \\
Departamento de Sociologia \\
Universidade de São Paulo
\end{tabular}

Resumo: Este artigo tem como objetivo contribuir para a compreensão do perfil socioeconômico e político-ideológico das bases sociais da Conlutas, central sindical e popular criada em 2004 a partir de uma dissidência da CUT, e que conta com a participação de diferentes movimentos sociais. A análise tem como base um survey realizado durante o $1^{\circ}$ Congresso Nacional da Conlutas, ocorrido em julho de 2008 na cidade de Betim (MG). Os dados mostram que a Conlutas representa, em sua maioria, trabalhadores não manuais, do setor público, especialmente da educação, que recebem até 3 salários mínimos e que têm uma situação de trabalho caracterizada pela estabilidade.

Palavras-chave: Conlutas; movimento sindical; movimentos sociais; governo Lula

Abstract: This article aims to contribute to the understanding of social and political-ideological profile of Conlutas, a trade union and popular organization created in 2004 as a CUT's dissidence, with the participation of different social movements. The analysis is based on a survey conducted during the Conlutas First National Congress, occurred in 2008 July in the city of Betim (MG//Brazil). The results show that Conlutas mainly represents non-manual workers from the public sector, particularly from education, who earn up to 3 minimum wages and have stable working conditions.

Keywords: Conlutas; trade unionism; social movements; Lula's government

OPINIÃO PÚBLICA, Campinas, vol. 19, no 1, junho, 2013, p. 81-117 


\section{Introdução}

O presente artigo apresenta os resultados preliminares de uma pesquisa mais ampla que vem sendo desenvolvida desde julho de 2008 sobre as bases sociais das centrais sindicais no Brasil contemporâneo $^{1}$. Esta pesquisa busca traçar, a partir de surveys realizados durante congressos e encontros sindicais, o perfil socioeconômico e político-ideológico das bases sociais de cada uma das centrais sindicais existentes hoje no Brasil.

Essa investigação justifica-se em função da reconfiguração pela qual vem passando o movimento sindical brasileiro, desde a ascensão do Partido dos Trabalhadores (PT) ao governo federal em 2003 e o consequente processo de cisão e fusão de centrais e correntes sindicais ${ }^{2}$. Foram criadas a Coordenação Nacional de Lutas (Conlutas), em 2004; a Intersindical e a Nova Central Sindical de Trabalhadores (NCST), em 2006; a União Geral dos Trabalhadores (UGT) e a Central dos Trabalhadores e Trabalhadoras do Brasil (CTB), em 2007. Conlutas, Intersindical e CTB são oriundas da CUT; NCST origina-se fundamentalmente a partir de federações e confederações da estrutura oficial; UGT surge a partir da fusão da Central Autônoma dos Trabalhadores (CAT), da Confederação Geral do Trabalho (CGT) e da Social Democracia Sindical (SDS). Essas novas centrais passam a compor, com a CUT, a Força Sindical e a Central Geral dos Trabalhadores do Brasil (CGTB), o atual cenário sindical no Brasil.

$\mathrm{O}$ objetivo deste artigo é analisar a Conlutas. Nossa análise tem como base um survey realizado durante $01^{\circ}$ Congresso Nacional desta central sindical, ocorrido em julho de 2008 na cidade de Betim (MG).

A Conlutas surge em março de 2004, a partir de algumas correntes que, até então, integravam a CUT: o Movimento por uma Tendência Socialista (MTS), ligado ao Partido Socialista dos Trabalhadores Unificado (PSTU) e algumas correntes do Partido Socialismo e Liberdade (PSOL), entre elas o Movimento de Esquerda Socialista (MÊS), o Movimento de Ação Sindical (MAS) e o Movimento Terra, Trabalho e Liberdade (MTL).

A saída dessas correntes foi provocada, fundamentalmente, por dois fatores. Em primeiro lugar, suas lideranças e seus militantes eram contrários à posição acrítica e passiva assumida pela CUT frente ao governo Lula, um governo que, além de manter os principais eixos da política macroeconômica do governo Fernando Henrique Cardoso, promoveu e/ou tentou implementar, sobretudo em seu primeiro mandato, uma série de reformas que reduziram ou ameaçavam reduzir direitos trabalhistas. Uma delas, a reforma da previdência realizada em 2003, levou à retirada de direitos dos servidores públicos, setor fortemente sindicalizado e com grande inserção junto à CUT. Em segundo lugar, essas correntes opunham-se à participação da central nos organismos tripartites (o Conselho de Desenvolvimento

${ }^{1}$ Foram pesquisadas, até o presente momento, as seguintes centrais: Coordenação Nacional de Lutas (Conlutas), União Geral dos Trabalhadores (UGT), Central dos Trabalhadores e Trabalhadoras do Brasil (CTB) e Intersindical. Realizamos também um survey durante o Conclat, Congresso que discutiu a unificação da Conlutas com a Intersindical. Trata-se de uma pesquisa interinstitucional, coordenada pelas autoras do presente artigo. A equipe responsável pela aplicação dos questionários é composta por pesquisadores da Unicamp, USP, UFU, e UNESP. Para a montagem do banco de dados, temos contado com o apoio do Centro de Estudos Marxista (Cemarx) e do Centro de Estudos de Opinião Pública (Cesop), particularmente de Rosilene Sydney Gelape.

2 Esse processo de reconfiguração se deve a razões de ordem político-ideológicas e também institucionais. A esse respeito, destaque-se o papel da Lei das Centrais (Lei 11.648/2008), que estabeleceu critérios de representatividade para reconhecer oficialmente as centrais sindicais existentes no país. 
Econômico e Social - CDES - e o Fórum Nacional do Trabalho - FNT) criados pelo governo para discutir as reformas previdenciária, tributária, trabalhista e sindical. Ao reunir representantes de governos, empresários e trabalhadores, esses organismos tripartites tinham como objetivo, na nossa compreensão, construir consensos em torno das questões mais polêmicas e minimizar uma eventual reação dos trabalhadores às políticas a serem adotadas. As correntes que formaram a Conlutas consideram o tripartismo uma forma de cooptação e de conciliação de classe. Além disso, opunham-se ao projeto de reforma em discussão, na medida em que entendiam que as mudanças pretendidas levariam à centralização do poder nas cúpulas sindicais, reduzindo o espaço de resistência das correntes minoritárias e funcionando, assim, como uma porta de entrada para a reforma trabalhista (GALVÃo, 2006; 2009).

A Conlutas constitui uma experiência inovadora no Brasil, uma vez que abrange não apenas entidades sindicais, mas também organizações populares e movimentos sociais urbanos e rurais. 0 movimento estudantil, por exemplo, tem grande presença em seu interior. Essa composição abrangente baseia-se em uma concepção de classe ampla e pela compreensão de que o proletariado não deve ser organizado apenas no local de trabalho. Ademais, a Conlutas procurou aglutinar este espectro de movimentos e organizações em torno de lutas gerais e específicas. Assim, a constituição da Conlutas se deu com o objetivo de "organizar a luta contra as reformas neoliberais do governo Lula (Sindical/Trabalhista, Universitária, Tributária e Judiciária) e também contra o modelo econômico que este governo aplica no país, seguindo as diretrizes do FMI" (CONLUTAS, 2004). Em 2006, na cidade de Sumaré, os participantes do Congresso Nacional dos Trabalhadores decidiram fundar oficialmente uma central sindical e popular, com o intuito de:

\footnotetext{
"Agrupar em seu interior os trabalhadores organizados nos sindicatos, os desempregados, os aposentados, os trabalhadores que se organizam nos diferentes movimentos populares e sociais da cidade e do campo, as organizações e movimentos que lutam contra toda a forma de discriminação e opressão, as organizações estudantis, as da juventude, e outras afins, que decidirem participar das lutas da classe trabalhadora" (CONLUTAS, 2006).
}

Desse modo, a Conlutas propõe-se a aglutinar setores muito heterogêneos e que defendem bandeiras variadas, mas que partilham posições antineoliberais e socialistas. Para denunciar as políticas neoliberais empreendidas e pretendidas pelo governo Lula, a Conlutas realizou variadas ações, tais como atos, marchas a Brasília, apoio a greves, ocupações de trabalhadores e promoção de encontros de movimentos populares como de negros e mulheres. Todavia, nem todos os setores dissidentes da CUT migraram para a Conlutas.

Outras correntes de esquerda da CUT, congregadas na Frente de Esquerda Sindical e Socialista (FES), cujos principais dirigentes eram ligados às correntes Alternativa Sindical Socialista (ASS), Unidade Classista (corrente sindical do Partido Comunista Brasileiro/PCB) e correntes do Partido Socialismo e Liberdade/PSOL (Enlace, Ação Popular Socialista/APS, Coletivo Socialismo e Liberdade/CSOL) criaram a Intersindical. A justificativa oficial para sua criação foi que a CUT teria deixado de ser um instrumento de 
organização e unificação do movimento sindical para ser um instrumento de colaboração e conciliação de classes. A criação de duas organizações distintas por parte dos setores de esquerda dissidentes da CUT pode ser explicada por três razões: 1) compreensões diferentes do que deve ser o trabalho de uma central $^{3}$, tal como afirmado no discurso oficial das centrais; 2) posições distintas diante do governo Lula, distinções essas que se expressam nas diferentes estratégias políticas do PSOL e do Partido Socialista dos Trabalhadores Unificado (PSTU), os dois partidos que são majoritários dentro da Intersindical e Conlutas, respectivamente; 3 ) descontentamentos por parte dos integrantes da Intersindical pelo fato de a Conlutas, cuja criação lhe antecede, estar atrelada ao PSTU4.

A despeito das diferenças que levaram à constituição de duas entidades sindicais nacionais distintas, a Intersindical e a Conlutas possuem uma grande proximidade político-ideológica: constituíram-se em oposição às medidas neoliberais do governo Lula e suas reformas; também apresentam um posicionamento crítico ao capital, recusando-se a negociar acordos que impliquem concessões e perdas de direitos aos trabalhadores. Essas afinidades político-ideológicas possibilitaram ações conjuntas (manifestações, greves), bem como um movimento de aproximação organizativa entre ambas. Em julho de 2010, a unificação da Conlutas com parte da Intersindical foi discutida no I Congresso da Classe Trabalhadora (Conclat); mas a fusão não se concretizou e esta possibilidade permanece em aberto 5 .

Apesar das contínuas mudanças organizativas que vêm se verificando no cenário sindical brasileiro e que afetam a própria Conlutas, como mencionamos anteriormente, este artigo analisa a Conlutas por considerar que sua criação representa uma novidade no sindicalismo brasileiro e evidencia um movimento de resistência ao neoliberalismo, que se manifesta numa conjuntura complexa, uma vez que se dá junto a um governo que possui laços estreitos com a parcela majoritária do movimento sindical $^{6}$. Além disso, não existem pesquisas sobre essa central; não há uma tradição investigativa consagrada na Sociologia Política brasileira que busque estudar sindicatos e centrais a partir de suas raízes sociais ${ }^{7}$. Quem são, então, os militantes da Conlutas? Qual é a base social dessa organização e quais são suas bandeiras de luta? Em que aspectos essa organização difere das demais centrais existentes no Brasil'? Que forças sociais a Conlutas aglutina?

\footnotetext{
${ }^{3}$ Uma diferença importante da Intersindical em relação à Conlutas é que nem todos os dirigentes e sindicatos que integram a Intersindical deixaram a CUT, optando por um duplo movimento: ao mesmo tempo em que avaliam que a resistência e o enfrentamento no interior da CUT não são mais suficientes, entendem que é preciso reconhecer a legitimidade daqueles que continuam lutando dessa forma (INTERSINDICAL, 2006). Nesse sentido, a Intersindical não se configura como uma central propriamente dita, pois isso implicaria que os sindicatos que participam dessa experiência saíssem da CUT.

${ }^{4}$ A esquerda cutista daria origem ainda a uma terceira organização: a Central de Trabalhadores e Trabalhadoras do Brasil (CTB). Fundada em 2007, a CTB é composta, sobretudo, por integrantes da Corrente Sindical Classista (CSC), ligados ao Partido Comunista do Brasil (PC do B)

${ }^{5}$ A despeito da não concretização da fusão, houve mudanças, a começar pela nomenclatura, uma vez que a Conlutas passou a se chamar Central Sindical e Popular (Conlutas).

${ }^{6} \mathrm{Com}$ exceção da Conlutas e da Intersindical, todas as demais centrais - as 6 oficialmente reconhecidas - apoiam o governo. Assim, o governo Lula realiza a proeza de ter em sua base de sustentação duas centrais tradicionalmente rivais. Sobre 0 processo de convergência entre CUT e FS ver: Galvão (2006; 2009) e Trópia (2010).

7 Exceção aos trabalhos de Rodrigues (1990), Rodrigues e Cardoso (1993) e Jácome Rodrigues (1997).

8 A comparação com outras centrais sindicais justifica-se devido ao predomínio de entidades sindicais no interior da Conlutas, como revela nossa pesquisa.
} 


\section{Quem é, afinal, a Conlutas?}

Para compreender o início desse processo dinâmico de reconfiguração do sindicalismo brasileiro, realizamos um survey durante o $1^{\circ}$ Congresso Nacional da Conlutas, ocorrido entre os dias 3 a 6 de julho de 2008, em Betim, Minas Gerais, a fim de identificar o perfil dos delegados e das entidades participantes.

Entre delegados e observadores, inscreveram-se no I Congresso 3.566 pessoas. Desse total, estiveram presentes 2.805 delegados, representantes de 583 entidades, de todas as regiões do país ${ }^{9}$ (Tabela 1):

Tabela 1

Entidades e delegados do $1^{\circ}$ Congresso da Conlutas

\begin{tabular}{l|c|c|}
\hline & Entidades & Congressistas \\
\hline Inscritos & 810 & 3.566 \\
\hline Presentes & 583 & 2.805 \\
\hline Participantes* & 368 & 368 \\
\hline Delegados & 353 & 353 \\
\hline \multicolumn{2}{|c|}{ Fonte: Banco de Dados da Conlutas e Banco de dados das pesquisadoras. } \\
* Delegados, observadores e participantes que não se identificaram.
\end{tabular}

O tipo de organização da Conlutas é bastante peculiar, já que ela filia não apenas entidades oficialmente reconhecidas pelo Estado e seus dirigentes, mas também membros de oposições ${ }^{10}$. Isso vale tanto para sindicatos como para o movimento estudantil. Dentre os delegados, $65,3 \%$ representavam entidades sindicais (inclusive oposições e minorias sindicais que se declararam como "outra entidade") e 34,7\% movimentos sociais (populares, estudantil e outras entidades), como podemos verificar pela Tabela 2 .

Vejamos, de forma mais detalhada, quais são as entidades de origem dos delegados da Conlutas. Note-se que, dentre os delegados do movimento sindical, a maioria representava sindicatos, seguida de minorias e oposições sindicais e, finalmente, federações e sindicatos nacionais. Dentre os representantes de movimentos sociais, por sua vez, a maioria representava entidades do movimento estudantil, seguida do movimento popular urbano, movimento popular do campo e, finalmente, organizações relacionadas à cultura, gênero, etc. A grande presença do movimento estudantil pode ser explicada pela oposição de segmentos do movimento estudantil à União Nacional dos Estudantes (UNE)

${ }^{9}$ Os dados da pesquisa foram levantados por meio de uma amostra intencional das entidades que participaram do $1^{\circ}$ Congresso. O objetivo foi colher o maior número possível de informações sobre as entidades filiadas à Conlutas e o perfil dos militantes dessas entidades. Assim, decidiu-se que seria entrevistado um delegado de cada uma das entidades inscritas no Congresso. Das 583 entidades presentes, a equipe de pesquisadores identificou 368. Como o critério de amostragem foi definido segundo o número de entidades, entrevistou-se um delegado de cada uma das 368 identificadas. Dos questionários aplicados, 353 compõem nossa base de dados, pois excluímos de nossa análise 13 observadores e 2 participantes que não se identificaram. 0 questionário foi aplicado aos delegados ao longo dos quatro dias de duração do Congresso. Inicialmente, os delegados eram abordados por um dos componentes da equipe de pesquisadores e, depois de identificada a entidade de filiação, um questionário com 50 perguntas, das quais 7 abertas e 43 fechadas, era aplicado. Os dados foram tratados com o programa SPSS (Statistical Package for the Social Sciences).

10 Essas oposições podem ser bastante diminutas: havia oposições registradas como entidade com direito a voz e voto no congresso cuja base era de duas pessoas. 
- então dominada pelo Partido Comunista do Brasil (PC do B) e pelo Partido dos Trabalhadores (PT) - e pelo trabalho de base do PSTU junto a esse segmento.

Tabela 2

Delegados por tipo de movimento e entidade

\begin{tabular}{|l|c|c|c|}
\multicolumn{1}{|c|}{ Movimento Sindical } & N & Total (\%) \\
\hline Sindicatos & 142 & 61,8 & 40,3 \\
\hline Minorias de diretoria/Oposição sindical & 84 & 36,5 & 23,9 \\
\hline Federação e sindicatos nacionais & 4 & 1,7 & 1,1 \\
\hline \multicolumn{1}{|c|}{ Movimento Social } & 230 & 100 & 65,3 \\
\hline Subtotal & N & $\%$ & Total (\%) \\
\hline Movimento Estudantil & 75 & 61,5 & 21,3 \\
\hline Movimento popular urbano & 20 & 16,4 & 5,7 \\
\hline Movimento popular do campo & 19 & 15,6 & 5,4 \\
\hline Organização cultural, de mulheres, GLBT, antirracismo. & 8 & 6,6 & 2,3 \\
\hline Subtotal & 122 & 100 & 34,7 \\
\hline Total & 352 & 100 & 100 \\
\hline
\end{tabular}

Fonte: Banco de Dados da Conlutas e Banco de dados das pesquisadoras.

Dentre as entidades sindicais, $67 \%$ eram do setor público e $33 \%$ do setor privado, conforme mostra a Tabela $3^{11}$. Esse dado indica que a Conlutas é, em sua maioria, uma central que organiza sindicatos de funcionários públicos, uma base social bastante afetada pela reforma da previdência promovida pelo governo Lula, como mencionamos anteriormente.

Tabela 3

Tipo de entidade sindical por setor

\begin{tabular}{|l|c|}
\hline \multicolumn{1}{|c|}{ Setor } & $\%$ \\
\hline Setor público & 67 \\
\hline Setor privado & 33 \\
\hline Total & 100 \\
\hline Fonte: Banco de Dados da Conlutas e Banco de dados das pesquisadoras.
\end{tabular}

Dentre os sindicatos filiados à Conlutas, destacavam-se: Sindicato dos Trabalhadores da USP (Sintusp), Sindicato dos Trabalhadores no Serviço Público Federal de São Paulo (Sindsef), Sindicato Nacional dos Docentes das Instituições de Ensino Superior (Andes), Sindicato dos Trabalhadores nas

11 Não foi possível identificar o setor a que pertencem $10,5 \%$ das entidades sindicais. 
Indústrias Químicas de São José dos Campos e Região, Sindicato dos Metalúrgicos de São José dos Campos, Federação Sindical Democrática dos Metalúrgicos de Minas Gerais. É desta entidade, aliás, que provém um de seus dirigentes mais conhecidos, José Maria de Almeida.

Para compreendermos o perfil político-ideológico, as orientações e as posições assumidas pelas entidades presentes ao Congresso, além de suas alianças e conflitos, é necessário analisar suas bases sociais, bem como a forma como estas entidades representativas de classes e frações de classe posicionam-se nas diferentes conjunturas. É este o sentido mais profundo de representatividade política e social que motiva nossa pesquisa e o presente artigo. A próxima seção apresenta o perfil socioeconômico dos delegados.

\section{Perfil socioeconômico dos delegados}

Analisamos os dados relativos à idade, cor, nível de escolaridade, locais de nascimento e de domicílio, situação profissional, ocupacional e setor econômico em que trabalham, função ou cargo que exercem, tempo no trabalho atual, tempo no setor econômico, tipo de contrato e renda dos delegados.

Aproximadamente $2 / 3$ dos delegados da Conlutas são homens (64,6\% do total). Muito embora a presença de homens seja predominante, a participação das mulheres $(35,4 \%)$ deve ser destacada, sobretudo se considerarmos que, relativamente aos Congressos da CUT (1988, 1991 e 2009) e da Força Sindical (1991 e 2009), a presença de mulheres torna a Conlutas a entidade que mais agrega militantes do sexo feminino. No $1^{\circ}$ Congresso da Força Sindical, realizado em 1991 (RodRIGUES e CARDoso, 1993), $13,4 \%$ dos delegados eram do sexo feminino e no $6^{\circ}$ Congresso, ocorrido em 2009, as mulheres representavam 24,6\% (FORÇA SINDICAL, 2009). Nos $3^{\circ}$ e $4^{\circ}$ Congressos da CUT, a participação de mulheres correspondeu a $24,1 \%$ e $18,4 \%$, respectivamente (RODRIGUES, 1990). No último CONCUT, realizado em 2009, a presença das mulheres correspondia a pouco mais de $1 / 4$, ou seja, $26,3 \%$ (CARVAlho, 2009).

A maior incidência de mulheres no Congresso da Conlutas pode estar relacionada a duas ordens de fatores: primeiramente, à participação de movimentos sociais, e movimentos de mulheres, em particular, à presença de sindicatos cuja força de trabalho é basicamente feminina, como os sindicatos de professores, ou aqueles em que as mulheres têm uma grande inserção, como no serviço público. Em segundo lugar, para enfrentar tanto as mudanças no perfil da força de trabalho quanto a redução de quadros, os sindicatos passaram a incluir em suas pautas de negociação algumas das reivindicações das mulheres (tais como mecanismos de prevenção às LER e garantias às lesionadas; instrumentos para combater as discriminações salariais e acesso a treinamentos e postos de trabalho, ampliação da licença-maternidade), o que pode tê-las atraído para o sindicalismo.

Outra característica do perfil socioeconômico dos delegados refere-se à idade e ao tempo de militância. Quanto à faixa etária, os dados da Tabela 4 mostram que há uma tendência à concentração dos delegados na faixa entre 31 e 50 anos (47,9\% do total), muito embora duas faixas etárias mereçam nossa atenção: a de jovens entre 15 e 24 anos (23,2\%) - cuja participação resulta, muito provavelmente, da presença do movimento estudantil na entidade -, e a de maiores de 51 anos (15,9\%). De qualquer 
forma, ainda que a presença de jovens e de mulheres seja expressiva, a Conlutas ainda mantém esse tradicional traço do sindicalismo brasileiro: agregar mais homens do que mulheres e em uma faixa de idade que vai dos 31 aos 50 anos de vida.

Tabela 4

Delegados por faixa de idade

\begin{tabular}{|l|c|c|}
\hline Idade & N & \% \\
\hline 15 a 18 anos & 13 & 3,7 \\
\hline 19 a 24 anos & 69 & 19,5 \\
\hline 25 a 30 anos & 46 & 13 \\
\hline 31 a 40 anos & 66 & 18,7 \\
\hline 41 a 50 anos & 103 & 29,2 \\
\hline 51 a 68 anos & 56 & 15,9 \\
\hline Total & 353 & 100 \\
\hline
\end{tabular}

Os participantes do Congresso da Conlutas tinham, em média, uma idade superior à dos delegados da CUT participantes do Congresso de Belo Horizonte em 1988. De acordo com pesquisa realizada por Rodrigues (1990, p. 34), a média de idade dos delegados presentes ao $3^{\circ}$ CONCUT era 33,1 anos - média que, pode-se supor, seria ainda mais baixa quando do Congresso de Fundação da CUT. No que diz respeito à Força Sindical, tanto a mediana quanto a moda situavam-se em 38 anos (RodRIGUeS E CARDoso, 1993, p. 25), enquanto os delegados da Conlutas tinham em média 36,9 anos. Em relação ao tempo de atuação em partidos e movimentos sociais (Tabela 5), os delegados pesquisados tinham em média 10,2 anos de militância e estavam concentrados na faixa de 1 a 10 anos de militância. Todavia, enquanto a maioria absoluta dos delegados representantes dos movimentos sociais está concentrada na faixa de até 5 anos de militância $(58,5 \%$ ) - o que reflete a presença do movimento estudantil -, apenas a maioria relativa dos delegados do movimento sindical se encontra nesta faixa $(25,2 \%)$. Por sua vez, a metade dos delegados do movimento sindical tem um tempo de militância superior a 10 anos de militância, o que pode ser explicado pelo fato de a Conlutas ser composta por sindicalistas dissidentes de outras centrais, sobretudo da CUT. 
TRÓPIA, P. V.; GALVÃO, A.; MARCELINO, P. A reconfiguração do sindicalismo:...

Tabela 5

Tempo de militância em partidos e movimentos sociais, por tipo de delegado

\begin{tabular}{|l|c|c|c|c|c|c|}
\hline & \multicolumn{2}{|c|}{$\begin{array}{c}\text { Delegado do } \\
\text { movimento sindical }\end{array}$} & $\begin{array}{c}\text { Delegado do } \\
\text { movimento social }\end{array}$ & \multicolumn{2}{c|}{ Total } \\
\cline { 2 - 7 } & $\mathrm{N}$ & $\%$ & $\mathrm{~N}$ & $\%$ & $\mathrm{~N}$ & $\%$ \\
\hline Até 5 anos & 58 & 25,2 & 72 & 58,5 & 130 & 36,8 \\
\hline Mais de 5 a 10 anos & 35 & 15,2 & 20 & 16,3 & 55 & 15,6 \\
\hline Mais de 10 a 20 anos & 51 & 22,2 & 11 & 8,9 & 62 & 17,6 \\
\hline Mais de 20 a 30 anos & 50 & 21,7 & 7 & 5,7 & 57 & 16,1 \\
\hline Mais de 30 a 45 anos & 14 & 6,1 & 3 & 2,4 & 17 & 4,8 \\
\hline $\begin{array}{l}\text { Não sabe/não } \\
\text { respondeu }\end{array}$ & 22 & 9,6 & 10 & 8,1 & 32 & 9,1 \\
\hline Total & 230 & 100 & 123 & 100 & 353 & 100 \\
\hline
\end{tabular}

Fonte: Banco de Dados da Conlutas e Banco de dados das pesquisadoras.

Em relação à cor ${ }^{12}, 38,5 \%$ dos delegados da Conlutas declararam-se brancos, $22,7 \%$ pardos e $23,2 \%$ pretos. Se somarmos pretos e pardos, $45,9 \%$ dos pesquisados eram negros, portanto, a maioria relativa dos participantes. Indagados sobre seu estado civil, $45 \%$ eram solteiros e $42,8 \%$ eram casados ou viviam uma relação conjugal. Ao cruzarmos estado civil e sexo, descobrimos que a maioria absoluta dos solteiros é do sexo feminino $(54,4 \%)$ e, entre casados ou que viviam uma relação conjugal, 50,9\% eram do sexo masculino.

Relativamente ao perfil dos brasileiros, o nível de escolaridade dos delegados da Conlutas pode ser considerado alto, em função da incidência de delegados com nível superior completo e pós. graduação, 15,6\% e 15,6\%, respectivamente ${ }^{13}$. Ocorre uma concentração entre delegados que têm do Ensino Superior incompleto à Pós-Graduação (60,7\% do total, ver Tabela 6). 0 alto nível de escolaridade resulta da significativa presença de estudantes, professores e de funcionários públicos, conforme verificamos adiante, como também pode refletir uma mudança mais geral no sistema educacional brasileiro, com a expansão do Ensino Superior - sobretudo privado - em virtude das exigências crescentes de "qualificação" impostas pelo mercado de trabalho.

\footnotetext{
$12 \mathrm{O}$ dado referente à cor foi obtido a partir de uma questão aberta, na qual se solicitava a autoidentificação dos entrevistados. 0 agrupamento dos dados posteriormente realizado baseou-se na classificação do IBGE, com o intuito de padronizar os resultados e possibilitar comparações.

${ }^{13}$ Segundo dados da PNAD, apenas 7,3\% da população brasileira tinham 15 anos ou mais de estudo em 2007 e a região sudeste seria aquela que teria maior porcentagem: $8 \%$ do total.
} 
Tabela 6

Delegados por nível de escolaridade

\begin{tabular}{|l|c|c|}
\hline & N & $\%$ \\
\hline Analfabeto & 1 & 0,3 \\
\hline $1^{\circ}$ grau incompleto & 19 & 5,4 \\
\hline $1^{\circ}$ grau completo & 9 & 2,5 \\
\hline $2^{\circ}$ grau incompleto & 25 & 7,1 \\
\hline $2^{\circ}$ grau completo & 86 & 24,4 \\
\hline Superior incompleto & 103 & 29,2 \\
\hline Superior completo & 55 & 15,6 \\
\hline Pós-Graduação & 55 & 15,6 \\
\hline Total & 353 & 100 \\
\hline Fonte: Banco de Dados da Conlutas e Banco de dados das pesquisadoras.
\end{tabular}

Todos os delegados eram brasileiros natos. A maioria deles nasceu na região sudeste $(42,5 \%)$, seguida da região nordeste (29,5\%), sul (11,6\%), norte (10,5\%) e centro-oeste (5,9\%) do Brasil (Gráfico 1). Os estados da região sudeste com o maior número de delegados foram São Paulo e Rio de Janeiro. Fora da região sudeste destacam-se dois estados do nordeste, Ceará e Bahia; o estado do Pará na região norte e, entre os estados da região sul, o Rio Grande do Sul. Já na região centro-oeste, observa-se uma concentração de delegados nascidos em Goiás. Quanto à região de domicílio e onde se localiza a entidade, a situação não é diferente: predominam delegados que residem e que representam entidades situadas na região sudeste, seguidos das regiões nordeste, sul, norte e centro-oeste. A concentração de delegados representantes de entidades que se situam na região sudeste é característica tanto do movimento sindical (54,3\%), quanto dos movimentos sociais (45\%) da Conlutas. Os dados levantados entre os delegados do $1^{\circ}$ Congresso da Conlutas evidenciam, ademais, outra característica tradicional do movimento sindical, qual seja, ser mais organizado na região sudeste do que nas outras regiões do Brasil. 
TRÓPIA, P. V.; GALVÃO, A.; MARCELINO, P. A reconfiguração do sindicalismo:....

Gráfico 1

Delegados por região de nascimento, de domicílio e de localização da entidade (\%)

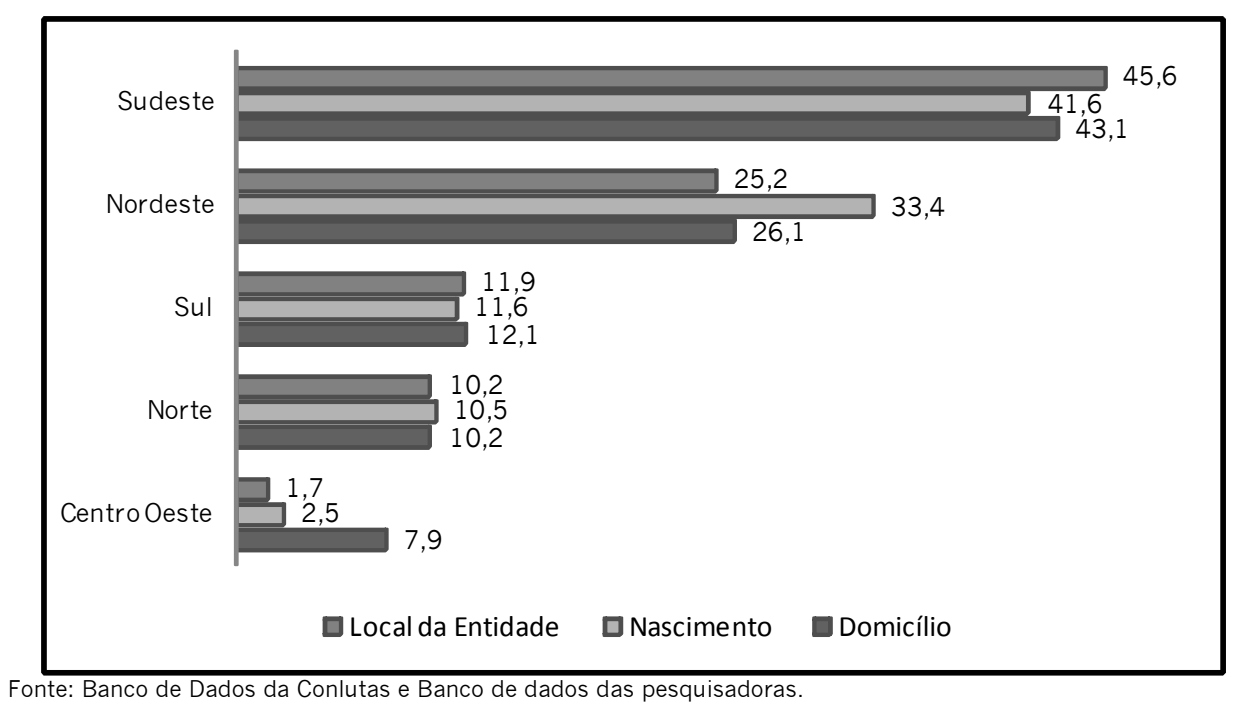

Analisemos agora a situação dos delegados da Conlutas em relação ao mercado de trabalho (Tabela 7). Quanto à situação de emprego, 68,5\% dos delegados encontravam-se empregados no momento da pesquisa; $14,1 \%$ eram estudantes; $6,5 \%$ estavam desempregados; $6,8 \%$ eram aposentados e $4,1 \%$ faziam "bicos", ou serviços informais e temporários. A condição de desempregado ou de trabalhador do setor informal é mais recorrente entre os representantes dos movimentos sociais, embora também haja representantes do movimento sindical que se encontravam desempregados. A situação ocupacional dos delegados é a seguinte: 
Tabela 7

Delegados por tipo de participação no Congresso, por situação de emprego (\%)

\begin{tabular}{|c|c|c|c|c|c|c|}
\hline & 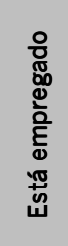 & 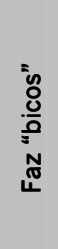 & 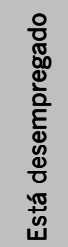 & 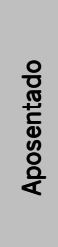 & 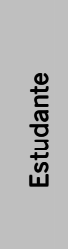 & $\begin{array}{l}\bar{\pi} \\
\text { 。ँ }\end{array}$ \\
\hline Delegado do movimento sindical & 89,4 & 0,9 & 1,4 & 8,3 & . & 100 \\
\hline Delegado do movimento social & 31,7 & 9,8 & 15,4 & 4,1 & 39 & 100 \\
\hline Total & 68,5 & 4,1 & 6,5 & 6,8 & 14,1 & 100 \\
\hline
\end{tabular}

No que diz respeito à situação ocupacional (Tabela 8), a maioria absoluta dos delegados era de funcionários públicos (55,6\%), 33,2\% empregados urbanos do setor privado, 9,2\% trabalhadores por conta própria, 0,4\% empregado ou assalariado rural, 0,4\% estagiário e 1,2\% profissionais liberais. Trata-se, assim, de uma central predominantemente urbana e enraizada no setor público, o que corrobora o dado anteriormente indicado relativo às entidades participantes. Dessa forma, destaca-se a baixa participação de trabalhadores rurais, com apenas um empregado rural e os demais, incluídos na categoria "autônomo/ por conta própria".

Tabela 8

Delegados por situação ocupacional

\begin{tabular}{|l|c|c|}
\hline & N & $\%$ \\
\hline Funcionário público & 139 & 55,6 \\
\hline Empregado ou assalariado urbano & 83 & 33,2 \\
\hline Autônomo/conta própria & 23 & 9,2 \\
\hline Profissional liberal & 3 & 1,2 \\
\hline Empregado ou assalariado rural & 1 & 0,4 \\
\hline Estagiário & 1 & 0,4 \\
\hline Total & $250 *$ & 100 \\
\hline
\end{tabular}

Quanto à profissão (Gráfico 2), os delegados da Conlutas apresentam o seguinte perfil: 27,3\% eram profissionais de nível médio, 23,8\% trabalhadores do serviço público cuja profissão não foi identificada, 9,7\% trabalhadores do comércio e serviços, 7,8\% eram profissionais de nível superior e $7,2 \%$ trabalhadores industriais qualificados e semi-qualificados. Note-se que há uma predominância de 
profissionais e trabalhadores não-manuais, em detrimento dos trabalhadores manuais urbanos e rurais. Se agruparmos, por sua vez, as profissões predominantemente não manuais, encontramos quase $2 / 3$ do total dos delegados $(65,2 \%)$, em contraste com $14,7 \%$ que eram trabalhadores manuais da indústria e $2,5 \%$ rurais.

Podemos afirmar até o momento que, em sua maioria, os delegados da Conlutas são homens, negros, com idade entre 30 e 50 anos, concentrados em ocupações do setor público e em profissões não-manuais. Vejamos os setores econômicos em que eles estão inseridos.

Gráfico 2

Delegados por profissão (\%)

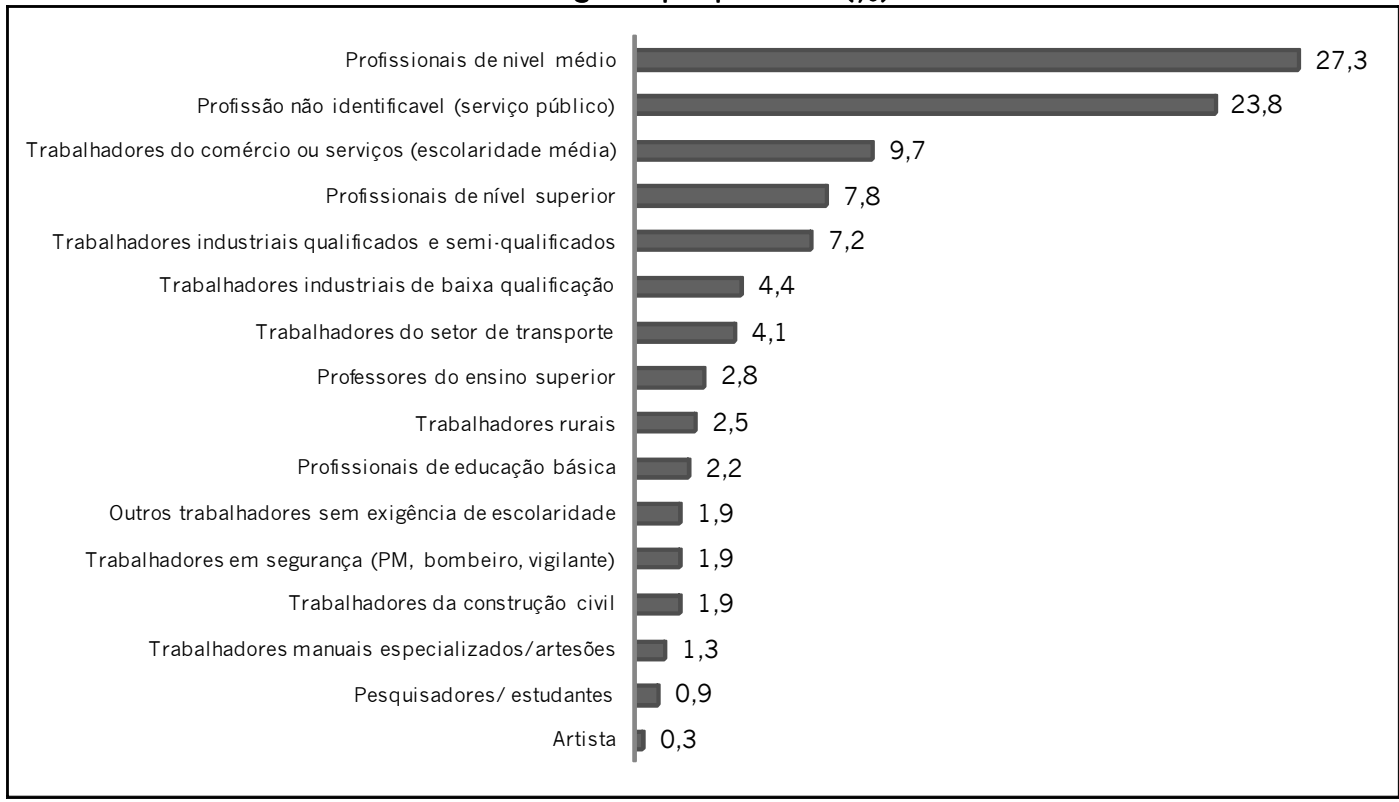

Fonte: Banco de Dados da Conlutas e Banco de dados das pesquisadoras.

Como mostra a Tabela 9, 35\% dos delegados estão inseridos no setor de Educação e Cultura, $16,1 \%$ no setor de Serviços, $15 \%$ no setor Industrial, 7,1\% no de Seguridade Social (Assistência Social e Saúde) e 5,5 \% no setor Financeiro. Ao cruzarmos o setor econômico pelo tipo de movimento dos delegados da Conlutas, notamos algumas peculiaridades: os delegados inseridos no setor industrial eram, durante o Congresso, majoritariamente representantes sindicais - o mesmo ocorrendo com os delegados do setor de seguridade social, sistema financeiro e transporte. Por sua vez, os delegados do setor do comércio e da agricultura eram predominantemente representantes de movimentos sociais. Assim, enquanto os delegados do movimento sindical estão concentrados no setor da Educação e Cultura, Serviços e Indústria, os delegados do movimento social estão concentrados no setor da Educação e Cultura, Agricultura, Comércio e Serviços. 
Embora já tenhamos apresentado algumas razões mais gerais e conjunturais que levaram a Conlutas a atrair para as suas fileiras, majoritariamente, sindicatos do setor público, bem como diversos movimentos sociais, a inserção dos delegados nos setores econômicos nos permite levantar algumas hipóteses. Em relação aos delegados inseridos no setor agrícola trata-se, muito provavelmente, de representantes de assentamentos rurais, muitos deles vinculados à corrente Movimento Terra, Trabalho e Liberdade - Democrático e Independente, que era uma dissidência do Movimento Terra, Trabalho e Liberdade (MTL) que, por sua vez, era uma dissidência do Movimento dos Trabalhadores Rurais sem Terra. O MTL saiu da Conlutas algumas semanas antes da realização do Congresso, o que nos ajuda a explicar porque o movimento no campo é, relativamente, pouco expressivo entre os movimentos sociais participantes. Em relação aos delegados inseridos no setor do comércio, pode-se supor que sejam representantes de movimentos sociais urbanos de luta por moradia ou movimentos ligados à opressão (de gênero, principalmente).

Tabela 9

Delegados por setor econômico e tipo de movimento (\%)

\begin{tabular}{|l|c|c|c|}
\hline & $\begin{array}{c}\text { Delegado do } \\
\text { movimento sindical }\end{array}$ & $\begin{array}{c}\text { Delegado do movimento } \\
\text { social }\end{array}$ & Total \\
\hline Educação e Cultura & 35,0 & 35,2 & 35,0 \\
\hline Serviços & 16,5 & 14,8 & 16,1 \\
\hline Indústria & 18,5 & 1,9 & 15,0 \\
\hline Seguridade Social & 8,5 & 1,9 & 7,1 \\
\hline Sistema Financeiro & 7,0 & $\cdot$ & 5,5 \\
\hline Transporte & 5,0 & 3,7 & 4,7 \\
\hline Comércio & 1,5 & 14,8 & 4,3 \\
\hline Agricultura & 1,0 & 16,7 & 4,3 \\
\hline Outros & 7,0 & 11,1 & 7,9 \\
\hline Total & 100 & 100 & 100 \\
\hline
\end{tabular}

Ao cruzarmos a profissão dos delegados da Conlutas com o setor econômico (Tabela 10), verificam-se interseções ou confluências, mas também alguma dispersão. Há uma correlação entre certas profissões e os respectivos setores econômicos. Assim, a maior parte dos trabalhadores rurais está concentrada no setor agrícola14; dos trabalhadores industriais (qualificados e semi-qualificados ou de baixa qualificação) no setor industrial; e dos funcionários públicos que não identificaram sua profissão no setor da Educação e Cultura. Entre os profissionais da Educação Básica predominam aqueles que estão inseridos na Educação; porém, há um delegado que atua na Seguridade Social, pois trabalha na Assistência Social como arte-educador.

14 Entre os agricultores, há um delegado que está inserido no setor Educação e Cultura, pois no momento da pesquisa ele trabalhava como servente em uma escola. 
TRÓPIA, P. V.; GALVÃO, A.; MARCELINO, P. A reconfiguração do sindicalismo:...

Já as profissões de nível superior e médio, trabalhadores manuais especializados/artesãos, trabalhadores do setor do comércio ou serviços e outras profissões sem exigência de escolaridade apresentam alguma dispersão entre os setores econômicos. As profissões de nível superior distribuem-se entre os setores de educação e cultura, serviços e outros setores; as profissões de nível médio distribuem-se entre os setores de seguridade social, educação e cultura e serviços; já os trabalhadores do comércio e serviços (com escolaridade média) estão dispersos entre os setores financeiro e de serviços e, paradoxalmente, pouco concentrados no próprio comércio.

Tabela 10

Profissão por setor econômico da ocupação atual (\%)

\begin{tabular}{|c|c|c|c|c|c|c|c|c|c|c|}
\hline & 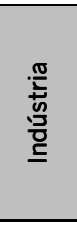 & 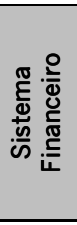 & 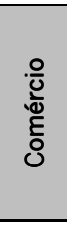 & 造 & 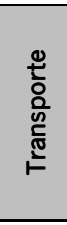 & 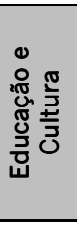 & 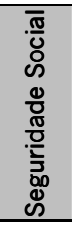 & $\begin{array}{l}\frac{\pi}{5} \\
\frac{5}{3} \\
\frac{0}{50} \\
\frac{0}{4}\end{array}$ & 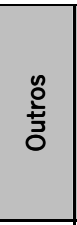 & 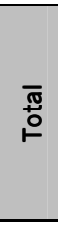 \\
\hline Trabalhadores rurais & . & . & . & - & . & 14,3 & & 85,7 & - & 100 \\
\hline Profissionais de nível superior & 4,8 & 4,8 & . & 19 & 4,8 & 28,6 & 4,8 & . & 33,3 & 100 \\
\hline Profissionais de nível médio & 10,3 & 2,6 & . & 23,1 & . & 23,1 & 30,8 & 2,6 & 7,7 & 100 \\
\hline $\begin{array}{l}\text { Trabalhadores industriais } \\
\text { qualificados e semi-qualificados }\end{array}$ & 75 & . & - & 25 & . & . & - & - & . & 100 \\
\hline $\begin{array}{l}\text { Trabalhadores industriais de baixa } \\
\text { qualificação }\end{array}$ & 100 & . & - & . & - & - & . & - & . & 100 \\
\hline $\begin{array}{l}\text { Trabalhadores manuais } \\
\text { especializados/artesãos }\end{array}$ & 25 & . & 50 & - & . & . & . & . & 25 & 100 \\
\hline Trabalhadores da construção civil & 50 & . & . & 33,3 & . & . & . & . & 16,7 & 100 \\
\hline $\begin{array}{l}\text { Trabalhadores do setor de } \\
\text { transporte }\end{array}$ & - & . & . & . & 91,7 & & 8,3 & . & . & 100 \\
\hline $\begin{array}{l}\text { Trabalhadores do comércio ou } \\
\text { serviços (escolaridade média) }\end{array}$ & . & 37 & 14,8 & 37 & . & 7,4 & . & . & 3,7 & 100 \\
\hline Professores do ensino superior & . & . & - & . & . & 100 & . & - & . & 100 \\
\hline Profissionais de educação básica & . & . & - & . & . & 85,7 & 14,3 & . & . & 100 \\
\hline $\begin{array}{l}\text { Trabalhadores em segurança (PM, } \\
\text { bombeiro, vigilante) }\end{array}$ & 20 & 20 & . & 40 & . & 20 & . & . & . & 100 \\
\hline Pesquisadores/ estudantes & . & . & . & . & . & 50 & . & . & 50 & 100 \\
\hline $\begin{array}{l}\text { Outros trabalhadores sem exigência } \\
\text { de escolaridade }\end{array}$ & . & . & 60 & 40 & . & . & . & . & . & 100 \\
\hline $\begin{array}{l}\text { Funcionário público com profissão } \\
\text { não identificável }\end{array}$ & 2,9 & 1,4 & . & 10 & . & 72,9 & 1,4 & 2,9 & 8,6 & 100 \\
\hline Artista & . & . & 100 & . & . & . & . & . & . & 100 \\
\hline Total & 14,5 & 5,8 & 4,1 & 16,5 & 5 & 35,5 & 6,6 & 3,7 & 8,3 & 100 \\
\hline
\end{tabular}

Fonte: Banco de Dados da Conlutas e Banco de dados das pesquisadoras.

No que diz respeito à função e aos cargos, a maioria dos delegados da Conlutas ocupava cargos ou funções não-manuais ( $71,1 \%$ do total). Do total de pesquisados, $37 \%$ ocupavam funções não-manuais 
de nível superior e média hierarquia, 19,6\% ocupavam cargos não-manuais de nível técnico e média hierarquia e $14,5 \%$ com pouca escolaridade e baixa hierarquia. Por sua vez, 12,3\% dos delegados ocupavam cargos e funções manuais com baixa qualificação e baixa hierarquia, enquanto $12,8 \%$ dos delegados desempenhavam funções manuais qualificadas. Assim, este perfil evidencia mais alguns traços importantes dos delegados da Conlutas: são trabalhadores não-manuais que ocupam predominantemente cargos ou funções de nível de escolaridade superior e de média hierarquia (Gráfico 3):

\section{Gráfico 3}

Delegados segundo função/cargo (\%)

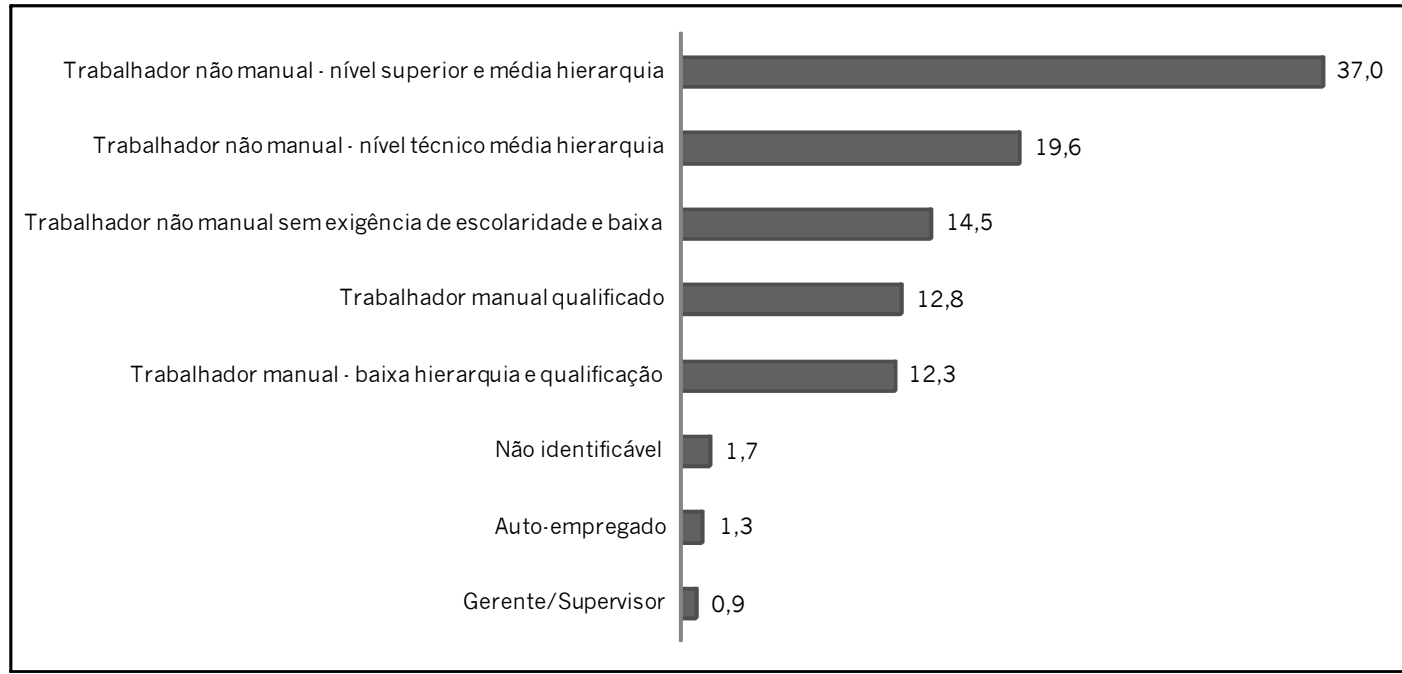

Fonte: Banco de Dados da Conlutas e Banco de dados das pesquisadoras.

Vejamos agora alguns aspectos relativos à situação no mercado de trabalho e à situação contratual dos delegados da Conlutas participantes do Congresso.

Com vistas a desvendar alguns aspectos relativos às condições de trabalho dos delegados da Conlutas, investigamos o tempo médio de trabalho no emprego atual. Haveria uma tendência à estabilidade ou à precariedade no emprego entre os delegados da Conlutas?

Pela Tabela 11, verificamos que 43,7\% dos delegados trabalhavam há mais de 10 anos no mesmo emprego; 23,3\% deles estavam entre 5 até 10 anos no mesmo emprego e 22\% trabalhavam entre 1 e 5 anos no mesmo emprego. Por sua vez, 11\% dos delegados trabalhavam há menos de 1 ano. Considerados os delegados que se encontravam empregados no momento da pesquisa, é possível afirmar que, devido à alta incidência de trabalhadores do setor público entre os pesquisados, a situação predominante é de estabilidade. Isso a despeito das mudanças introduzidas pela reforma administrativa de 1998, que não extinguiu completamente a estabilidade do funcionalismo público (assegurada após 3 anos de serviço, embora com possibilidade de perda de cargo em decorrência de avaliação periódica de 
desempenho), mas a flexibilizou, e da introdução de contratos precários no setor público, que comentamos brevemente adiante.

O tempo de permanência no setor econômico (Tabela 11) é outro indicador para conhecer o perfil dos delegados. Teriam os delegados da Conlutas vínculos estáveis com o setor econômico em que trabalhavam e com o emprego que detinham no momento da entrevista? Os dados levantados apontam a significativa incidência de delegados inseridos por um tempo longo no mesmo setor econômico. Note-se que é na faixa entre "mais de 10 a 20 anos" no mesmo setor econômico que encontramos a maior incidência de delegados da Conlutas (26,4\%). O mesmo ocorre em relação ao emprego atual, na medida em que $24,2 \%$ dos delegados concentravam-se na faixa entre "mais de 10 a 20 anos".

Tabela 11

Delegados por tempo de permanência no setor econômico e no emprego atual (\%)

\begin{tabular}{|l|c|c|}
\hline & Setor econômico & Emprego atual \\
\hline Até 1 ano & 8,2 & 11,0 \\
\hline Mais de 1 a 5 & 22,9 & 22,3 \\
\hline Mais de 5 a 10 & 16,3 & 24,2 \\
\hline Mais de 10 a 20 & 26,4 & 19,1 \\
\hline Mais de 20 a 35 anos & 24,9 & 0,4 \\
\hline Mais de 35 anos & 1,2 & 100 \\
\hline Total & 100 & 2 \\
\hline \multicolumn{2}{|c|}{ Fonte: Banco de Dados da Conlutas e Banco de dados das pesquisadoras. } \\
\hline
\end{tabular}

Passemos, agora, à análise da situação trabalhista dos delegados. Como sabemos, um dos efeitos mais perversos do neoliberalismo foram as perdas relativas aos direitos trabalhistas. A política de abertura econômica e de privatização das empresas públicas e de prestação de serviços levou ao crescimento do desemprego. A resposta dos governos neoliberais ao aumento do desemprego, que encontrou o apoio ativo de uma parte do movimento sindical, foi a implantação de uma reforma trabalhista que reduzia direitos (GALVÃO, 2007). As formas de contratação temporária foram ampliadas, introduziu-se a prática da suspensão temporária do contrato de trabalho, a terceirização foi disseminada e a informalidade foi significativamente aumentada a ponto de, em 2003, o trabalho informal representar $52 \%$ da PEA brasileira. O fato de a Conlutas combater no plano político-ideológico a plataforma neoliberal no Brasil, suscita, assim, um interesse algo especial. Afinal, o combate a tais políticas responde a demandas e problemas vivenciados pelas bases sociais da Conlutas? Pelos dados apresentados, acreditamos que sim: a plataforma de reivindicações dessa entidade sindical e popular corresponde às perdas que suas bases sociais sofreram com os consecutivos governos neoliberais desde Collor. Para citar alguns exemplos, a Lei $n^{\circ} 8.745 / 93$ admitiu o contrato por tempo determinado para 
atender a necessidades transitórias "de excepcional interesse público" da administração federal. A reforma administrativa aprovada em 1998 estabeleceu o fim da equiparação salarial, o fim do regime jurídico único (na medida em que se admite a contratação via Consolidação das Leis do Trabalho (CLT) forma de contrato que rege os trabalhadores do setor privado da economia - e a terceirização de serviços) e o fim da isonomia entre os três poderes; consagrou a implantação de mecanismos de avaliação de desempenho dos servidores e aumentou o período de experiência. Ao invés de reverter tais medidas, as perdas foram ampliadas no governo Lula, com a aprovação da reforma da previdência em 2003. Esta reforma, que teve como alvo a aposentadoria dos funcionários públicos, estabeleceu um teto para o benefício, igualando a aposentadoria dos novos servidores à do Regime Geral da Previdência Social (setor privado). Assim, os novos servidores deixaram de ter direito à aposentadoria integral e à paridade com os servidores ativos (deixando, portanto, de ter seus benefícios reajustados na mesma proporção que aqueles). Apesar de a assinatura de um Termo de Ajustamento de Conduta com o Ministério Público do Trabalho em 2002 ter resultado no aumento do número de funcionários públicos, a terceirização ainda é grande, em especial, na universidade, com a contratação de serviços privados de segurança e alimentação. Por fim, embora o governo tenha sustentado um discurso contrário à privatização, a celebração de parcerias público-privadas e a difusão de organizações sociais afeta a forma de contratação no serviço público. Esses elementos indicam que havia motivos para o surgimento de uma nova central com uma plataforma antineoliberal e fortemente vinculada ao funcionalismo público, nas suas várias instâncias.

Essas são considerações importantes porque, se consideramos apenas o tipo de contrato, o recurso à terceirização e o grau de formalização das relações de trabalho, a incidência da precarização sobre os delegados da Conlutas poderia passar despercebida.

Quanto ao tipo de contrato (Tabela 12), 71,4\% dos delegados tinham contrato por prazo indeterminado e 7,5\% por prazo determinado. Tanto entre funcionários públicos, quanto entre assalariados urbanos, predominava o contrato por prazo indeterminado. Outro indicador importante acerca da situação trabalhista dos delegados dizia respeito à condição de terceirizados. Do total, 92,6\% estavam contratados diretamente pela empresa principal e 7,4\% por empresas terceiras no momento da pesquisa. Indagados se já haviam trabalhado como terceirizados, a maioria absoluta afirmou que não $(71,4 \%$ do total). 
TRÓPIA, P. V.; GALVÃO, A.; MARCELINO, P. A reconfiguração do sindicalismo:...

Tabela 12

Tipo de contrato por ocupação

\begin{tabular}{|c|c|c|c|c|c|c|c|c|}
\hline & $\mathrm{N}$ & $\%$ & $\begin{array}{l}\text { Funcionário } \\
\text { público }\end{array}$ & $\begin{array}{c}\text { Empregado ou } \\
\text { assalariado } \\
\text { urbano }\end{array}$ & $\begin{array}{l}\text { Autônomo/ } \\
\text { conta própria }\end{array}$ & $\begin{array}{l}\text { Profissional } \\
\text { liberal }\end{array}$ & Estágio & Total \\
\hline $\begin{array}{l}\text { Contrato por prazo } \\
\text { indeterminado }\end{array}$ & 172 & 71,4 & 59,8 & 39,1 & 0,6 & 0,6 & . & 100 \\
\hline $\begin{array}{l}\text { Contrato de prazo } \\
\text { determinado }\end{array}$ & 18 & 7,5 & 44,4 & 38,9 & 5,6 & 5,6 & 5,6 & 100 \\
\hline $\begin{array}{l}\text { Contrato por pessoa } \\
\text { jurídica }\end{array}$ & 4 & 1,7 & $\cdot$ & 66,7 & . & 33,3 & . & 100 \\
\hline $\begin{array}{l}\text { Contrato em tempo } \\
\text { parcial }\end{array}$ & 1 & 0,4 & . & 100 & . & . & . & 100 \\
\hline Contrato de safra & 3 & 1,2 & - & 33,3 & 66,7 & . & . & 100 \\
\hline Outro & 43 & 17,8 & 58,5 & 9,8 & 31,7 & . & . & 100 \\
\hline Total & 241 & 100 & 56,6 & 34,5 & 7,2 & 1,3 & 0,4 & 100 \\
\hline
\end{tabular}

Fonte: Banco de Dados da Conlutas e Banco de dados das pesquisadoras.

Conforme a Tabela 13, do total dos delegados, 58\% tinham carteira assinada. Embora $42 \%$ deles tenham afirmado não possuir carteira, este dado não deve ser entendido como sinônimo de alta informalidade, pois o regime de trabalho predominante no setor público ainda é o Regime Jurídico Único, que confere aos servidores um estatuto próprio e diferente da CLT. Os delegados que não tinham carteira assinada eram majoritariamente funcionários públicos e autônomos.

Tabela 13

Delegados com e sem carteira assinada, por ocupação (\%)

\begin{tabular}{|l|c|c|c|}
\hline & $\begin{array}{c}\text { Com carteira } \\
\text { assinada }\end{array}$ & $\begin{array}{c}\text { Sem carteira } \\
\text { assinada }\end{array}$ & Total \\
\hline Funcionário público & 46,9 & 53,1 & 100 \\
\hline $\begin{array}{l}\text { Empregado ou assalariado rural (inclusive boia- } \\
\text { fria) }\end{array}$ & $\cdot$ & 100,0 & 100 \\
\hline Empregado ou assalariado urbano & 91,6 & 8,4 & 100 \\
\hline Autônomo/conta própria & 4,5 & 95,5 & 100 \\
\hline Profissional liberal & 33,3 & 66,7 & 100 \\
\hline Estágio & $\cdot$ & 100,0 & 100 \\
\hline Total & 58,0 & 42,0 & 100 \\
\hline
\end{tabular}

Fonte: Banco de Dados da Conlutas e Banco de dados das pesquisadoras.

Os dados relativos à renda são bastante interessantes e ajudam a revelar mais um traço importante do perfil dos delegados da Conlutas. Como vimos até aqui, é possível afirmar que a Conlutas é composta, em sua maioria, por homens, negros, residentes nas regiões sudeste e nordeste do Brasil, com nível de escolaridade superior (completo e incompleto), que realizam trabalho não-manual, ocupam 
cargos de média hierarquia, encontram-se inseridos no setor público, trabalham no mesmo setor econômico e no mesmo emprego por um período entre 10 e 20 anos e, finalmente, dispõem de uma situação trabalhista caracterizada pela formalidade, pelo estabelecimento de contratos por tempo indeterminado e firmados diretamente com as empresas nas quais exercem sua atividade.

Porém, ao considerarmos a posição dos delegados com relação à distribuição por faixa de renda, identificamos um dado revelador do seu perfil socioeconômico. Como mostra a Tabela 14, os delegados de todos os setores ocupacionais identificados estavam, no momento da pesquisa, predominantemente concentrados na faixa salarial de "0 até 3 salários mínimos" (45,2\% do total). Isso embora sejam trabalhadores predominantemente não-manuais e com nível de escolaridade superior. Se tomarmos a faixa salarial de "0 a 5 salários mínimos", nada menos do que 71,4\% dos delegados estariam nesta faixa salarial, de modo que a maioria absoluta dos delegados presentes no $1^{\circ}$ Congresso Nacional da Conlutas recebiam até 5 salários mínimos ${ }^{15}$.

Este dado relativo à renda da maioria dos delegados da Conlutas ("0 a 3 salários mínimos") é muito interessante porque revela, de um lado, um contraste entre o nível de escolaridade, o grau de responsabilidade da função/cargo exercido (média hierarquia), a relativa estabilidade no emprego (devido ao predomínio de servidores públicos), e, de outro, a remuneração recebida. Esse contraste pode ser explicado pelo arrocho salarial que afetou o funcionalismo público após a adoção do Plano Real (1994) e pela desestruturação da carreira após a reforma administrativa de 1998, ações estatais que, certamente, contribuem para explicar a criação da Conlutas.

Tabela 14

Delegados por ocupação e renda, em salários mínimos (\%)

\begin{tabular}{|c|c|c|c|c|c|c|}
\hline & $\begin{array}{c}\text { Até } 3 \\
\text { salários } \\
\text { mínimos }\end{array}$ & $\begin{array}{l}\text { De } 3 \text { a } 5 \\
\text { salários } \\
\text { mínimos }\end{array}$ & $\begin{array}{c}\text { De } 5 \text { a } 10 \\
\text { salários } \\
\text { mínimos }\end{array}$ & $\begin{array}{c}\text { Mais de } 10 \\
\text { salários } \\
\text { mínimos }\end{array}$ & $\begin{array}{l}\text { Não } \\
\text { tenho } \\
\text { renda }\end{array}$ & Total \\
\hline Funcionário público & 36 & 30,9 & 20,9 & 12,2 & - & 100 \\
\hline $\begin{array}{l}\text { Empregado ou assalariado } \\
\text { rural (inclusive boia-fria) }\end{array}$ & - & - & - & - & 100,0 & 100 \\
\hline $\begin{array}{l}\text { Empregado ou assalariado } \\
\text { urbano }\end{array}$ & 54,9 & 24,4 & 12,2 & 7,3 & 1,2 & 100 \\
\hline Autônomo/conta própria & 63,6 & 9,1 & 18,2 & 4,5 & 4,5 & 100 \\
\hline Profissional liberal & 66,7 & - & 33,3 & - & - & 100 \\
\hline Estágio & 100,0 & - & - & - & - & 100 \\
\hline Total & 45,2 & 26,2 & 17,7 & 9,7 & 1,2 & 100 \\
\hline
\end{tabular}

Fonte: Banco de Dados da Conlutas e Banco de dados das pesquisadoras.

${ }^{15}$ A retirada dos estudantes do cálculo não altera muito esse perfil: a faixa salarial até "3 salários mínimos" passa para $41 \%$. Já quando consideramos a renda de "O até 5 salários mínimos", o montante cai de $71,4 \%$ para $64,1 \%$. De qualquer forma, a maioria permanece como analisamos. 


\section{Perfil político-ideológico dos delegados da Conlutas}

O que defendem, onde militam e por quais causas mobilizam-se os delegados presentes ao Congresso da Conlutas? Com estas indagações iniciais, procuramos traçar o perfil político-ideológico dos delegados da Conlutas. Levantamos diferentes aspectos referentes às relações, práticas e concepções políticas dos delegados. Inicialmente, analisamos os dados relativos à sua percepção sobre as relações de opressão existentes na sociedade brasileira e, em um segundo momento, os dados relativos à inserção político-partidária, ao tempo de militância e às suas orientações políticas e sindicais.

Como afirmamos na introdução deste artigo, a Conlutas é expressão, na conjuntura do governo Lula, da resistência ao neoliberalismo por parte de setores dissidentes ou críticos à CUT e ao Partido dos Trabalhadores, bem como de variados movimentos sociais que se aglutinam em torno das lutas gerais e específicas. Vejamos como essas motivações mais gerais mobilizam a Conlutas e como elas se expressam em suas bases.

Inicialmente, procuramos identificar as formas de opressão que os delegados da Conlutas já haviam sofrido. Do total de delegados pesquisados, $94 \%$ afirmaram já terem sido alvo de alguma forma de opressão, índice que, além de alto, é significativo. Os delegados da Conlutas, muito provalvemente em função da experiência partidária e política acumulada no movimento sindical e social, tendem a ter uma percepção crítica das relações sociais. Esta percepção social aguçada diz respeito aos preconceitos de classe, gênero e raça.

Dentre os delegados que afirmaram já ter sofrido alguma forma de opressão (Gráfico 4), 64,9\% apontaram o preconceito de classe, $31 \%$ o de gênero e $20,1 \%$ de raça. Já o preconceito motivado por opção sexual foi indicado por 10,4\%, enquanto o preconceito motivado por doença/deficiência foi assinalado por $5,6 \%$ dos delegados. Vários delegados assinalaram mais de uma forma de preconceito sofrido - possibilidade dada pelo enunciado da questão. Os preconceitos de classe, gênero e raça foram, nesta ordem, os mais frequentes. São formas de preconceito que se manifestam de diversas maneiras, inclusive sobrepondo-se umas às outras. Por exemplo, o preconceito de classe pode se manifestar socialmente por meio da discriminação em relação à cor, ao tipo físico, à origem social (ser migrante, nordestino, de família pobre, residente em bairros periféricos) ou aos postos de trabalho subalternos.

Ao desdobrar os dados, encontramos algumas relações interessantes. Entre as mulheres, a principal forma de preconceito identificada foi a de gênero $(39,8 \%)$, seguida do preconceito racial $(25,4 \%)$ e de classe $(24,3 \%)$. Entre os homens, ao contrário, o preconceito de classe foi apontado pela maioria absoluta, $66 \%$ do total de homens, enquanto o preconceito racial por $20,1 \%$ deles. A predominância do preconceito de gênero sobre o preconceito de raça ou classe entre as mulheres, inclusive entre as negras, pode ser expressão da presença de vários movimentos de mulheres no $1^{\circ}$ Congresso da Conlutas, que lutam contra o machismo e a persistência de desigualdades de gênero nos mais diversos espaços sociais. 
Gráfico 4

Formas de opressão/discriminação por sexo (\%)

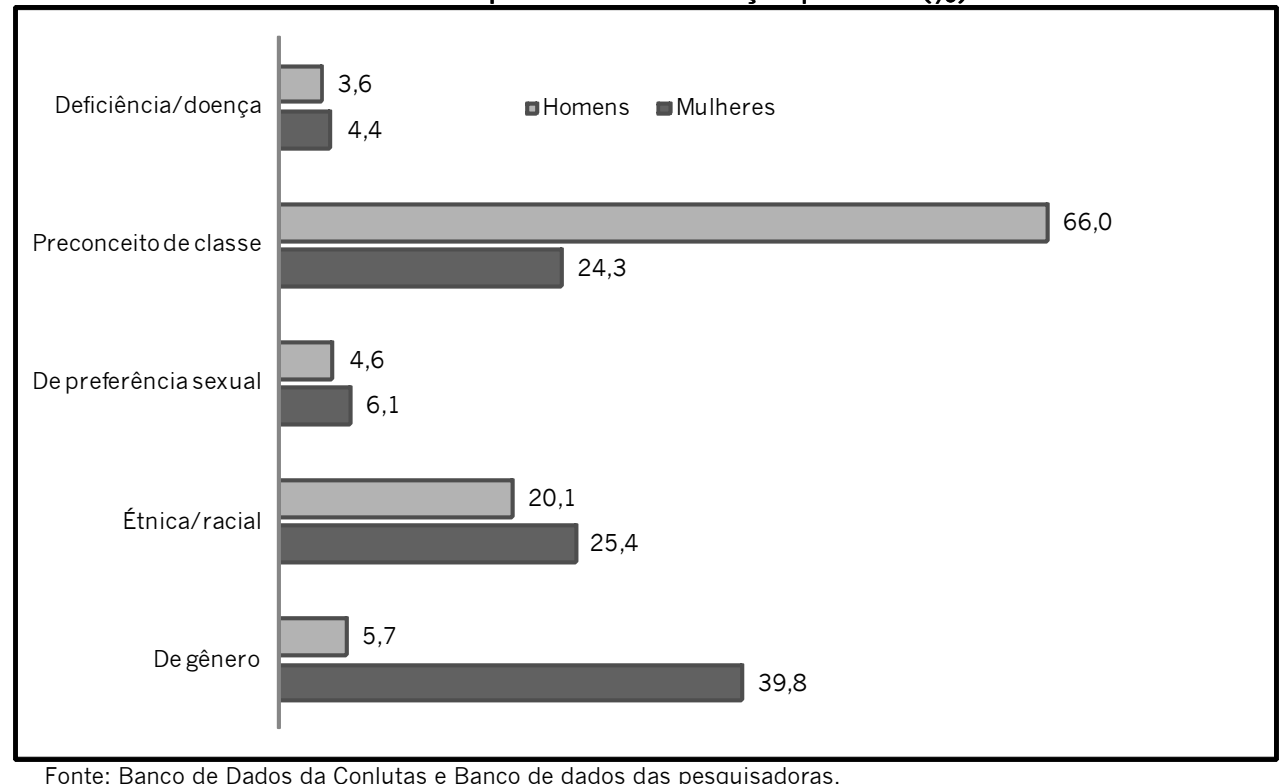

Fonte: Banco de Dados da Conlutas e Banco de dados das pesquisadoras.

Entre mulheres brancas e negras, a principal forma de opressão identificada foi a de gênero, embora entre as negras a diferença entre o percentual de preconceito de gênero e de preconceito de classe tenha sido menor. Entre os homens brancos, a principal forma de opressão foi a de classe, enquanto entre os homens negros foi a racial. Assim, o preconceito racial é especialmente opressivo na opinião dos delegados negros da Conlutas, enquanto o preconceito de gênero é mais sentido por suas delegadas brancas ou negras.

Tabela 15

Cor e gênero dos delegados por forma de preconceito (\%)

\begin{tabular}{|c|c|c|c|c|c|}
\hline \multicolumn{2}{|c|}{} & De gênero & Étnica/ racial & $\begin{array}{c}\text { De preferência } \\
\text { sexual }\end{array}$ & $\begin{array}{c}\text { De preconceito de } \\
\text { classe }\end{array}$ \\
\hline \multirow{3}{*}{ Branca } & Masculino & 3,0 & 10,0 & 49,0 & 43,0 \\
\cline { 2 - 6 } & Feminino & 51,0 & $\cdot$ & 13,0 & 3,0 \\
\hline \multirow{3}{*}{ Preta } & Masculino & 3,0 & 75,0 & $\cdot$ & 15,0 \\
\cline { 2 - 6 } & Feminino & 11,0 & 10,0 & 13,0 & 3,0 \\
\hline \multirow{3}{*}{ Parda } & Masculino & 8,0 & $\cdot$ & 25,0 & 35,0 \\
\cline { 2 - 6 } & Feminino & 23,0 & 5,0 & $\cdot$ & 1,0 \\
\hline Total & & 100 & 100 & 100 & 100 \\
\hline
\end{tabular}

Fonte: Banco de Dados da Conlutas e Banco de dados das pesquisadoras. 
TRÓPIA, P. V.; GALVÃO, A.; MARCELINO, P. A reconfiguração do sindicalismo:...

Há também uma correlação entre as formas de opressão e a renda dos delegados da Conlutas de tal modo que quanto maior a renda, menor é a incidência do preconceito. Embora a incidência de preconceito entre os delegados que não tinham renda seja menor do que aqueles que percebem "até 3 salários mínimos", este dado não deve ser interpretado como um paradoxo, na medida em que os delegados sem renda são, majoritariamente, estudantes.

Tabela 16

Delegados por Renda (em Salários Mínimos) e forma de preconceito (\%)

\begin{tabular}{|l|c|c|c|c|c|c|}
\hline & Até 3 SM & De 3 a 5 SM & De 5 a 10 SM & $\begin{array}{c}\text { Mais de 10 } \\
\text { SM }\end{array}$ & $\begin{array}{c}\text { Sem } \\
\text { renda }\end{array}$ & Total \\
\hline De gênero & 35,9 & 33,3 & 10,3 & 5,1 & 15,4 & 100 \\
\hline Étnica/ racial & 52,0 & 24,0 & 8,0 & 4,0 & 12,0 & 100 \\
\hline De preferência sexual & 33,3 & 22,2 & 11,1 & 11,1 & 22,2 & 100 \\
\hline De preconceito de classe & 43,0 & 21,5 & 18,7 & 3,7 & 13,1 & 100 \\
\hline Deficiência/ doença & 50,0 & 12,5 & 25,0 & - & 12,5 & 100 \\
\hline
\end{tabular}

Fonte: Banco de Dados da Conlutas e Banco de dados das pesquisadoras.

Quando perguntados sobre a preferência partidária (Tabela17), 78,2\% dos delegados da Conlutas disseram ter alguma preferência. Destes, $72,5 \%$ preferiam o PSTU e $11,4 \%$ o PSOL ${ }^{16}$.

Tabela 17

Delegados por preferência partidária (\%)

\begin{tabular}{|l|c|}
\hline \multicolumn{1}{|c|}{ Partidos } & $\%$ \\
\hline PSTU & 72,5 \\
\hline PSOL & 11,8 \\
\hline Outras preferências no campo da esquerda & 5,7 \\
\hline Pequenas agremiações de esquerda & 4,7 \\
\hline PSOL.PSTU.PCB, PSB, PDT e PV & 3,3 \\
\hline PSDB e PMDB & 1,0 \\
\hline PT & 0,9 \\
\hline Total & 100 \\
\hline
\end{tabular}

Em relação à filiação partidária, 59\% dos delegados da Conlutas eram, no momento do Congresso, filiados a partido político; $13,3 \%$ dos delegados afirmaram que, embora no momento não

${ }^{16}$ Apenas para termos uma perspectiva comparativa, quando realizou sua pesquisa sobre a CUT, Rodrigues (1990) identificou que $91 \%$ dos delegados presentes preferiam o PT. 
estivessem filiados, já o haviam feito anteriormente e, finalmente, 27,5\% afirmaram nunca terem se filiado.

Os resultados de nossa pesquisa corroboram a opinião bastante difundida segundo a qual a Conlutas agrega militantes filiados ao PSTU. A origem da Conlutas foi marcada pela atuação de lideranças daquele partido e, como afirmamos na Introdução, agregou e aproximou entidades descontentes com o PT e com a CUT. Segundo nossa pesquisa, 72,6\% dos delegados presentes no $1^{\circ}$ Congresso eram filiados ao PSTU; $17,4 \%$ ao PSOL e 2,5\% ao PT.

Sendo a preferência e o vínculo partidários da maioria dos delegados o PSTU, 59,2\% deles afirmaram terem votado neste partido no primeiro turno da eleição presidencial de 2006; afirmaram terem votado no PT $16,1 \%$ dos delegados e $12,9 \%$ anularam seu voto.

Tabela 18

Votação no primeiro turno das eleições presidenciais de 2006 (\%)

\begin{tabular}{|l|c|}
\hline Candidato & $\%$ \\
\hline Heloísa Helena (PSOL/PSTU/PCB) & 59,2 \\
\hline Lula (PT/ PRB/ PC do B) & 16,1 \\
\hline Cristovam Buarque (PDT) & 2,6 \\
\hline Geraldo Alckmin (PSDB/PFL) & 1,7 \\
\hline Outro & 6,6 \\
\hline Voto nulo & 12,9 \\
\hline Voto em branco & 0,9 \\
\hline Total & 100 \\
\hline
\end{tabular}

O tempo de militância em movimentos sociais e partidos políticos é um importante vetor para compreendermos o perfil político-ideológico dos delegados da Conlutas. A Tabela 19 mostra que 30,2\% dos delegados tinham mais de "20 anos de militância", 5\% tinham "menos de 1 ano de militância"; 48,6\% tinham "entre 1 e 9 anos de militância" e 16,2\% "mais de 10 anos até 19 anos de militância". 
TRÓPIA, P. V.; GALVÃO, A.; MARCELINO, P. A reconfiguração do sindicalismo:...

Tabela 19

Delegados por tempo de militância (em números absolutos e \%)

\begin{tabular}{|l|c|c|}
\hline Tempo de militância & N & $\%$ \\
\hline Menos de 1 ano & 16 & 5,0 \\
\hline Mais de 1 até 3 anos & 69 & 21,5 \\
\hline Mais de 4 até 5 anos & 45 & 14,0 \\
\hline Mais de 6 até 9 anos & 42 & 13,1 \\
\hline Mais de 10 até 19 anos & 52 & 16,2 \\
\hline Mais de 20 anos & 97 & 30,2 \\
\hline Total & $321 *$ & 100 \\
\hline
\end{tabular}

Para captar outros indicadores da participação política dos delegados, procuramos saber se, excluído o vínculo partidário, eles eram membros de alguma outra organização além daquela que representavam no Congresso da Conlutas. Os resultados da pesquisa apontam que 55,2,\% dos delegados não eram membros de outra organização, enquanto $44,8 \%$ responderam que mantinham vínculos com outras organizações. Nossa pesquisa evidenciou que se trata de organizações de naturezas bastante diversas, tais como organizações profissionais (assinaladas por 25,5\% dos delegados), organizações estudantis $(17,7 \%)$, políticas $(15,6 \%)$, bem como organizações rurais/urbanas relativas à questão fundiária $(13,5 \%)$ e organizações de gênero (7,8\%). Ademais, a maioria absoluta dos delegados já havia participado anteriormente de congressos sindicais e/ou de movimentos sociais (77,7\% do total), inclusive do $1^{\circ}$ Congresso da Classe Trabalhadora (CONAT), em 2006, durante o qual a Conlutas foi criada e do qual teriam participado cerca de $37 \%$ dos delegados.

Para explorar o perfil político-ideológico das bases sociais da Conlutas, solicitamos aos delegados que opinassem sobre uma série de questões relativas à estrutura sindical, aos direitos trabalhistas e a algumas políticas governamentais (Tabela 20). Entendemos aqui por estrutura sindical o arcabouço que rege a constituição e o funcionamento dos sindicatos no Brasil cujos princípios básicos, estabelecidos nos anos 1930, foram consubstanciados na CLT (1943) e permanecem como a base fundamental da organização sindical até o presente ${ }^{17}$.

17 A despeito das várias mudanças por que passou o sindicalismo brasileiro desde o governo Vargas, a Constituição Federal de 1988 manteve o princípio da unicidade sindical na base e ampliou as contribuições sindicais compulsórias que financiam os sindicatos que gozam do monopólio da representação de uma determinada categoria profissional. Assim, à contribuição sindical e à taxa assistencial veio se somar a contribuição confederativa. As duas últimas têm seus valores definidos em assembleia e a cobrança dos não filiados é passível de contestação na Justiça, pois a jurisprudência vigente a partir de 1996 entende que a extensão dessa cobrança aos não filiados fere o princípio constitucional da livre sindicalização. Já a contribuição sindical é paga por todo trabalhador, seja ele filiado ou não à sua entidade sindical e seu valor corresponde ao salário de um dia de trabalho. 
Tabela 20

Opiniões dos delegados sobre estrutura sindical, direitos trabalhistas e políticas governamentais (\%)

\begin{tabular}{|l|c|}
\hline Opinião & $\%$ \\
\hline Favorável à reforma da previdência & 48,1 \\
\hline Contrário à reforma da previdência & 46,3 \\
\hline Os direitos trabalhistas previstos na CLT e na Constituição de 1988 beneficiam o trabalhador & 3,8 \\
\hline $\begin{array}{l}\text { Os direitos trabalhistas previstos na CLT e na Constituição de 1988 beneficiam o trabalhador, } \\
\text { mas são insuficientes }\end{array}$ & 80,9 \\
\hline $\begin{array}{l}\text { Os direitos trabalhistas previstos na CLT e na Constituição de 1988 protegem em demasia o } \\
\text { trabalhador prejudicando sua autonomia } \\
\text { Os direitos trabalhistas previstos na CLT e na Constituição de 1988 prejudicam a } \\
\text { competitividade do trabalhador brasileiro } \\
\text { direitos trabalhistas }\end{array}$ & 2,1 \\
\hline É necessário haver alguma mudança na CLT na parte referente à organização sindical & 3,8 \\
\hline É necessário haver alguma mudança na CLT na parte referente aos direitos trabalhistas & 47,0 \\
\hline É contrário às contribuições compulsórias & 13,0 \\
\hline É favorável às contribuições compulsórias & 4,8 \\
\hline $\begin{array}{l}\text { É contra a unicidade sindical (entende que pode haver uma disputa entre organizações } \\
\text { sindicais distintas) }\end{array}$ & 72,4 \\
\hline É a favorável à unicidade sindical & 21,0 \\
\hline
\end{tabular}

Fonte: Banco de Dados da Conlutas e Banco de dados das pesquisadoras.

Em relação ao imposto sindical, dentre os pesquisados, $72,4 \%$ defendiam a extinção das contribuições compulsórias e $21 \%$ eram favoráveis a elas. Em relação ao princípio da unicidade sindical, a crítica é mais nuançada: embora $47,8 \%$ sejam contrários à unicidade, uma parte significativa é favorável a ela (40\%) e 12,2\% não têm posição a respeito. Se retirarmos aqueles delegados que não souberam responder, 45,5\% seriam favoráveis à unicidade. Estes dados podem indicar o peso da estrutura sindical brasileira e a dificuldade, sobretudo das lideranças sindicais, em lidar com um cenário de liberdade e autonomia do sindicalismo, ainda que esta seja uma ideia presente no discurso da maior parte das lideranças da própria Conlutas.

Quando perguntados sobre os direitos assegurados pela legislação brasileira, $80,9 \%$ dos delegados entenderam que os direitos trabalhistas previstos na CLT e na Constituição de 1988 beneficiam o trabalhador, mas são insuficientes. Indagados sobre a necessidade de mudanças na CLT, $64,9 \%$ do total dos delegados consideraram ser necessária alguma mudança, de tal forma que $47 \%$ consideraram que tais mudanças deveriam ser feitas tanto na parte referente à organização sindical quanto na parte referente aos direitos trabalhistas; $13 \%$ responderam que deveria haver mudanças somente na parte referente à organização sindical e 4,8\% na parte referente aos direitos trabalhistas. Apenas $18 \%$ não consideraram necessário mudar a CLT. O conteúdo dessa mudança não fazia parte da questão, mas, uma vez que $80,9 \%$ dos delegados disseram que os direitos trabalhistas são insuficientes e uma vez que a central se constitui em oposição aos efeitos do neoliberalismo, é possível inferir que a 
mudança almejada teria como propósito ampliar o escopo de direitos existentes e não flexibilizá-los. Finalmente, quando indagados sobre a necessidade de uma nova reforma da previdência, os delegados dividiram-se: $48,1 \%$ foram favoráveis e $46,3 \%$ contrários.

Cruzando os dados entre os delegados de acordo com o tipo de entidade representada e os dados colhidos sobre reforma da previdência, podemos observar que os delegados sindicais foram predominantemente contrários $(51,4 \%)$ a uma nova reforma, enquanto os delegados de movimentos sociais foram favoráveis $(55,4 \%)$ a uma nova reforma da previdência. É preciso aqui destacar que a pergunta não fazia referência a nenhum conteúdo específico de uma eventual nova reforma da previdência, mas se considerarmos que $89,4 \%$ dos delegados sindicais estão empregados e $8,3 \%$ são aposentados, isso pode significar que, para esse público, uma nova reforma pode significar perda de direitos, sugerindo uma explicação de sua oposição a ela. De modo correlato, se considerarmos que $15,4 \%$ dos delegados de movimentos sociais estão desempregados, 9,8\% fazem "bicos" e 39\% são estudantes, ou seja, ou não estão inseridos no mercado de trabalho ou estão inseridos precariamente, o apoio a uma nova reforma poderia ser considerado uma oportunidade de acesso à Previdência Social.

Tabela 21

Posicionamento dos Delegados quanto a uma nova Reforma da Previdência, por tipo de movimento e renda (\%)

\begin{tabular}{|l|l|c|c|c|c|}
\hline & & Sim & Não & Não sabe & Total \\
\hline \multirow{5}{*}{$\begin{array}{l}\text { Delegado do movimento } \\
\text { sindical }\end{array}$} & Até 3 SM & 42,5 & 53,4 & 4,1 & 100 \\
\cline { 2 - 6 } & De 3 a 5 SM & 43,3 & 50,7 & 6 & 100 \\
\cline { 2 - 6 } & De 5 a 10 SM & 42,6 & 53,2 & 4,3 & 100 \\
\cline { 2 - 6 } & Mais de 10 SM & 51,9 & 48,1 & & 100 \\
\cline { 2 - 6 } & Não tenho renda & 75 & 25 & & 100 \\
\cline { 2 - 6 } & Subtotal & 44,5 & 51,4 & 4,1 & 100 \\
\hline \multirow{5}{*}{$\begin{array}{l}\text { Delegado do movimento } \\
\text { social }\end{array}$} & Até 3 SM & 63,9 & 32,8 & 3,3 & 100 \\
\cline { 2 - 6 } & De 3 a 5 SM & 30 & 60 & 10 & 100 \\
\cline { 2 - 6 } & De 5 a 10 SM & 33,3 & 50 & 16,7 & 100 \\
\cline { 2 - 6 } & Não tenho renda & 51,4 & 37,1 & 11,4 & 100 \\
\hline & Subtotal & 55,4 & 37,5 & 7,1 & 100 \\
\hline
\end{tabular}

Fonte: Banco de Dados da Conlutas e Banco de dados das pesquisadoras.

Considerando-se que, entre os delegados sindicais, a situação ocupacional e no mercado de trabalho é mais estável do que os delegados de movimentos sociais, buscamos identificar se haveria alguma relação entre estabilidade no emprego e contratual e opinião sobre a reforma. Pois bem, uma nova reforma da previdência tende a ser rejeitada quanto mais estável é a situação contratual dos 
delegados; em contrapartida, tende a ser apoiada por aqueles menos estáveis e que percebem "entre 0 até 3 salários mínimos".

\section{0 perfil das entidades filiadas à Conlutas}

Apresentamos, finalmente, o perfil das entidades representadas pelos delegados participantes do Congresso da Conlutas ${ }^{18}$.

Como indicamos na primeira seção (Quem é, afinal, a Conlutas?) do presente artigo, embora a Conlutas não seja uma central sindical stricto sensu, na medida em que se propõe a agregar uma diversidade de movimentos sociais, é evidente o predomínio de entidades sindicais em seu interior. Esse predomínio, provavelmente, fez com que ela solicitasse seu registro como central sindical junto ao Ministério do Trabalho e Emprego. A Conlutas - que depois da tentativa de fusão com a Intersindical passou a ser denominada CSP.Conlutas - ainda não é, oficialmente, reconhecida como uma central, pois não apresenta as condições necessárias exigidas por lei, ou seja, 5\% do total de empregados sindicalizados em âmbito nacional.

Em função da peculiaridade organizativa da Conlutas, o $1^{\circ}$ Congresso contou com a participação de delegados que representavam sindicatos, oposições sindicais, minorias sindicais (grupos minoritários internos às direções sindicais) e movimentos sociais - populares, estudantis. Como sabemos, em geral, participam de congressos sindicais, as direções e parte das bases, além dos observadores. No Congresso da Conlutas, o modelo de participação era diferente, na medida em que incluía as oposições sindicais, que tinham grande presença tanto nos sindicatos do setor público quanto do setor privado.

A despeito dessa novidade, a estratégia da Conlutas parece ter sido, predominantemente, a disputa de entidades já existentes, e não a constituição de entidades paralelas (estabelecendo na prática o pluralismo sindical $)^{19}$. Isso reflete a relativa divisão a respeito do pluralismo, como constatamos ao analisar o perfil político-ideológico dos delegados.

Se comparado ao setor privado, o setor público revela uma maior presença de delegados que não ocupavam cargos na direção, nem integravam movimentos de oposição sindical, relativamente aos delegados que se declararam, simplesmente, associados.

\footnotetext{
18 Nossa análise leva em conta apenas as informações fornecidas pelos delegados sobre as entidades que representavam no momento do Congresso.

19 Entendemos por pluralismo sindical a possibilidade - impedida hoje por lei - de se constituir mais de um sindicato por base territorial numa mesma categoria profissional, em conformidade com o direito de livre organização dos trabalhadores preconizado pela OIT na sua convenção 87. Apesar do dispositivo legal, essa possibilidade vigora "de fato" para o sindicalismo de cúpula.
} 
TRÓPIA, P. V.; GALVÃO, A.; MARCELINO, P. A reconfiguração do sindicalismo:....

Tabela 22

Delegados sindicais conforme setor e tipo de participação na entidade sindical (\%)

\begin{tabular}{|l|c|c|c|c|}
\hline & $\begin{array}{c}\text { Faz parte da } \\
\text { direção }\end{array}$ & $\begin{array}{c}\text { Faz parte da } \\
\text { oposição } \\
\text { sindical }\end{array}$ & $\begin{array}{c}\text { É apenas } \\
\text { associado }\end{array}$ & Total \\
\hline Sindicato do Setor Público & 50 & 31,5 & 18,5 & 100 \\
\hline Sindicato de Setor Privado & 55,9 & 37,3 & 6,8 & 100 \\
\hline Total & 48,5 & 35,8 & 15,7 & 100 \\
\hline
\end{tabular}

Fonte: Banco de Dados da Conlutas e Banco de dados das pesquisadoras.

Dados a presença e o peso das entidades sindicais no interior da Conlutas, a pesquisa continha questões que se referiam exclusivamente a elas. Assim, procuramos verificar qual a importância das contribuições sindicais para o financiamento das entidades de natureza sindical. Nota-se que 66,4\% das entidades sindicais arrecadam a contribuição sindical obrigatória e, dessas, 21,05\% devolvem aos trabalhadores sindicalizados a parte da contribuição que lhes caberia por lei ${ }^{20}$. Importante ressaltar que vários sindicatos do setor público manifestam arrecadar a contribuição sindical21. 0 Gráfico 5 relaciona a prática da arrecadação com o tipo de sindicato:

\footnotetext{
20 Uma vez que 9,3\% das entidades arrecadam mais de uma contribuição, o total de respostas é superior a $100 \%$.

21 Ainda há uma controvérsia jurídica em relação à incidência das contribuições compulsórias sobre os funcionários públicos estatutários. No que se refere à contribuição sindical, a CLT não inclui explicitamente os funcionários públicos entre os trabalhadores passíveis de tributação. A Constituição de 1988, embora estenda o direito de sindicalização aos funcionários públicos (artigo 37), não é clara sobre a cobrança da contribuição sindical (mencionada no inciso IV do artigo $8^{\circ}$ ) para estes trabalhadores, nem da contribuição confederativa (instituída pelo referido inciso). A controvérsia deu origem a uma extensa jurisprudência por parte do Superior Tribunal de Justiça e do Supremo Tribunal Federal, sendo que alguns juristas entendem que a cobrança da contribuição sindical sobre os funcionários requer lei complementar. Finalmente, o Ministério do Trabalho e Emprego baixou a Instrução Normativa n $1 / 2008$ para regular a questão, estabelecendo que: "Os órgãos da administração pública federal, estadual e municipal, direta e indireta, deverão recolher a contribuição sindical prevista no art. 578, da CLT, de todos os servidores e empregados públicos, observado o disposto nos artigos 580 e seguintes da Consolidação das Leis do Trabalho". Ainda assim, há divergências quanto à competência do Ministério do Trabalho e Emprego para normatizar uma questão de natureza tributária. Também pairavam dúvidas sobre a extensão da taxa assistencial aos funcionários públicos, ao que o MTE respondeu com a Ordem de Serviço $N^{\circ} 01$, de 24 de março de 2009: "É possível a cobrança da contribuição assistencial de todos os trabalhadores".
} 
Gráfico 5

Forma de arrecadação das contribuições compulsórias por tipo de sindicato (\%)

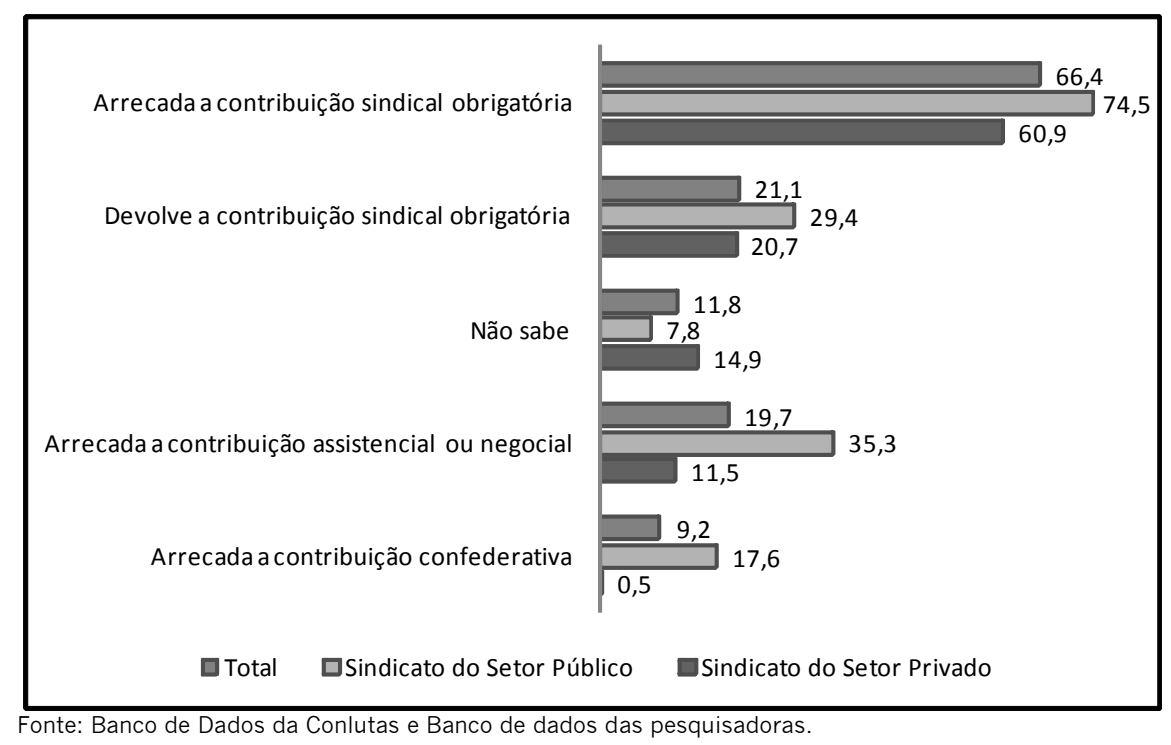

Vimos, anteriormente, que a maioria dos delegados presentes ao Congresso posicionaram-se contrariamente ao imposto sindical ( $72,4 \%$ do total). 0 Gráfico 6 mostra, entretanto, algumas tendências que apontam um paradoxo entre a posição dos delegados quanto às contribuições compulsórias e a prática de arrecadação de suas entidades. Quando cruzamos a opinião dos delegados em relação às contribuições compulsórias (se favorável ou contrária ao imposto sindical) e a prática da entidade em relação à arrecadação dessas contribuições, verifica-se que aproximadamente metade dos delegados que opinaram contrariamente às contribuições compulsórias (60\%) também disseram que suas entidades devolvem-nas (29,5\%). Ou seja, metade das entidades destes delegados não devolve a contribuição sindical obrigatória, evidenciando que no interior da Conlutas permanece a dependência financeira dos sindicatos em relação ao imposto sindical.

Esta dependência fica ainda mais evidente quando excluímos aquelas entidades que devolvem o imposto sindical e os casos daqueles delegados que não souberam responder. Afinal, o fato de $73,8 \%$ dos delegados representantes do movimento sindical afirmarem que suas entidades arrecadam algum tipo de contribuição (assistencial, confederativa e negocial/assistencial) é muito significativa para um congresso em que a maioria dos delegados declararam-se contrários a essas contribuições. 


\section{Gráfico 6}

Forma de Arrecadação por tipo de contribuição (\%)

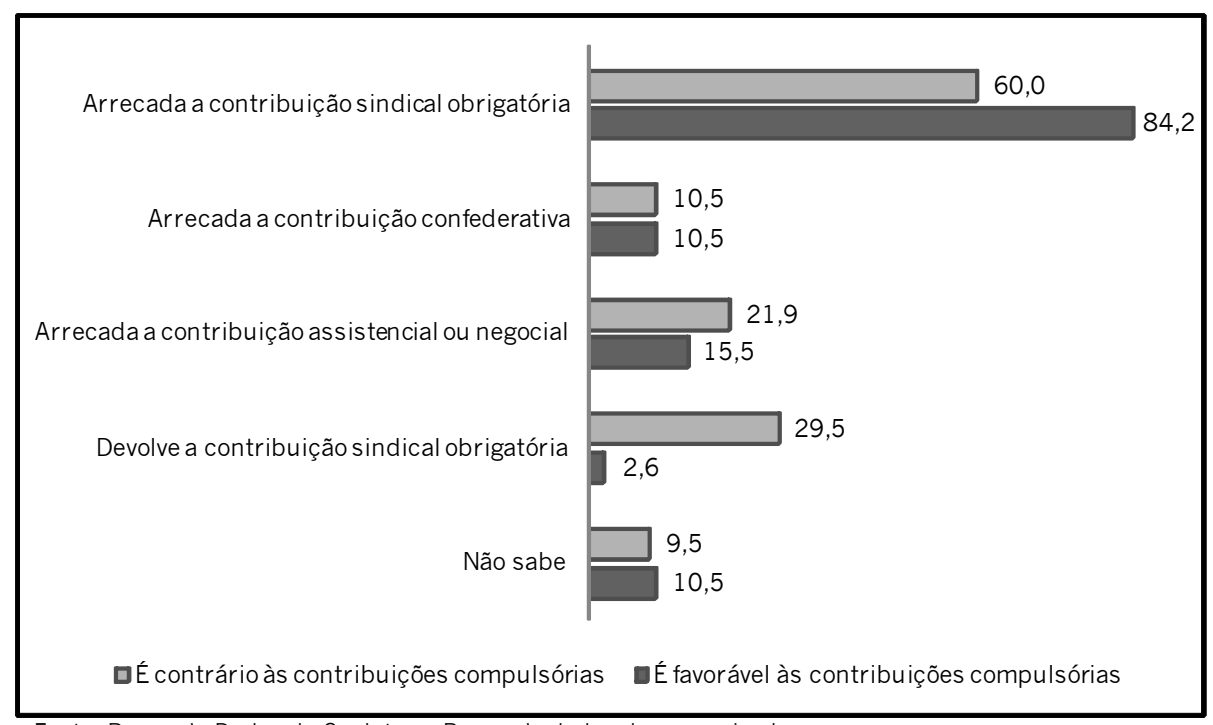

Fonte: Banco de Dados da Conlutas e Banco de dados das pesquisadoras.

Ainda no que se refere à estrutura interna das entidades, procuramos obter informações relativas: a) ao tempo de atuação dos delegados nas entidades que representavam; b) ao número de diretores da entidade; c) ao tempo de permanência no cargo de direção; d) à forma de composição da direção e e) à abrangência territorial da base.

Em relação ao tempo de atuação na entidade, 61,1\% dos delegados vinham atuando nela por um período de até 5 anos; $19 \%$ dos delegados entrevistados atuavam em suas entidades entre 5 a 10 anos; 19,9\% há mais de 10 anos. Não há, contudo uma correlação direta entre o tempo de militância e o tempo de atuação na entidade sindical. Embora a maioria dos delegados da Conlutas (56,9\% do total), como já assinalamos, tivesse um tempo de militância no movimento sindical e em partidos políticos superior a 20 anos - sendo, portanto, pessoas com larga experiência de militância -, o tempo de atuação na diretoria da entidade representada era menor. Dentre os delegados da Conlutas com cargos na diretoria de suas entidades, $75 \%$ dos entrevistados encontravam-se na direção por período igual ou inferior a 5 anos.

Vejamos agora os dados relativos ao número de diretores e à forma de composição da direção. Nossa pesquisa revela que 35,8\% dos delegados afirmaram que suas entidades tinham entre 11 e 20 diretores, 32,8\% entre 21 e 54 diretores e 29,9\% até 10 diretores. Quanto à composição da direção, $57,3 \%$ dos delegados afirmaram que sua entidade assume uma forma de organização colegiada, $31 \%$ presidencialista e $6,6 \%$ não souberam responder. 
Dentre os membros de diretoria das entidades sindicais, 33,7\% estavam liberados em tempo integral para exercer as atividades sindicais, enquanto 16,3\% estavam liberados em tempo parcial; $50,0 \%$ dos delegados membros de diretorias sindicais não tinham nenhuma liberação para exercer o mandato.

Voltando ao conjunto dos delegados, isto é, incluindo-se novamente os delegados de movimentos sociais em nossa análise, quando perguntados sobre a abrangência territorial da base representada pela entidade, verifica-se que $33,5 \%$ são entidades estaduais, $21 \%$ municipais e $18,4 \%$ têm um outro território por referência (como por exemplo, bairros, núcleos em escolas, entidades ou universidades).

Em relação ao número de filiados às entidades, a pesquisa revelou que 49,3\% dos delegados participantes do Congresso representavam entidades de até 2 mil filiados ${ }^{22}$. Quando desagregados por tipo de entidade, os dados relativos ao número de membros da base indicam que as entidades com menor número de filiados se concentravam entre os delegados de movimentos populares, estudantil e de outras entidades. Inversamente, entidades com maior número de membros são sindicatos, sobretudo do setor público.

Tabela 23

Entidades por tamanho

\begin{tabular}{|l|c|c|c|c|c|c|c|c|}
\hline & \multicolumn{2}{|c|}{$\begin{array}{c}\text { Sindicato do setor } \\
\text { público }\end{array}$} & \multicolumn{2}{|c|}{$\begin{array}{c}\text { Sindicato do setor } \\
\text { privado }\end{array}$} & $\begin{array}{c}\text { Movimento popular, } \\
\text { estudantil e outras } \\
\text { entidades }\end{array}$ & \multicolumn{3}{c|}{ Total } \\
\cline { 2 - 10 } & $\mathbf{N}$ & $\%$ & $\mathbf{N}$ & $\%$ & $\mathbf{N}$ & $\%$ & $\mathbf{N}$ & $\%$ \\
\hline Até 500 & 20 & 20,2 & 15 & 15,15 & 64 & 64,6 & 99 & 28,3 \\
\hline Mais de 500 até 2000 & 34 & 46,6 & 13 & 17,8 & 26 & 35,7 & 73 & 21,0 \\
\hline Mais de 2000 até 5 mil & 32 & 54,2 & 14 & 20,3 & 13 & 22,0 & 59 & 16,7 \\
\hline $\begin{array}{l}\text { Mais de 5 mil até 10 } \\
\text { mil }\end{array}$ & 15 & 50,0 & 8 & 26,7 & 7 & 23,3 & 30 & 8,5 \\
\hline $\begin{array}{l}\text { Mais de 10 mil até 50 } \\
\text { mil }\end{array}$ & 14 & 42,4 & 6 & 18,2 & 13 & 39,4 & 33 & 9,3 \\
\hline Mais de 50 mil & 10 & 71,4 & 3 & 21,4 & 1 & 7,1 & 14 & 4,0 \\
\hline $\begin{array}{l}\text { Não sabe/ não } \\
\text { respondeu }\end{array}$ & 13 & 25,0 & 9 & 17,3 & 30 & 57,7 & 43 & 12,2 \\
\hline
\end{tabular}

Fonte: Banco de Dados da Conlutas e Banco de dados das pesquisadoras.

Uma das questões mais relevantes para conhecermos o perfil das entidades da Conlutas referese às suas principais bandeiras de lutas. Em função da natureza da Conlutas e do perfil socioeconômico e político-ideológico exposto até aqui, compreende-se porque encontramos variadas bandeiras de lutas na pesquisa. São bandeiras que expressam desde questões e problemas gerais, relativos à conjuntura do país, até questões e problemas específicos, afeitos aos diversos setores que compunham a Conlutas naquele momento. Além das questões mais gerais (aglutinadas na Tabela 24), havia questões bastante

22 Esse tipo de dado é sempre muito difícil de ser mensurado, dada a tendência, já identificada nas pesquisas sobre o tema, de os dirigentes inflarem o tamanho de sua organização. Embora a pergunta se referisse ao número de filiados, as respostas parecem ter sido dadas em relação à base total, e não somente aos efetivamente associados. 
pontuais, tais como: assistência a meninos e meninas de rua; questões relativas à autonomia da entidade - como, por exemplo, do sindicalismo frente ao Estado e aos patrões ou do movimento estudantil em relação aos dirigentes governamentais e reitores -; igualdade social (racial, nas relações de gênero etc.); desfiliação da CUT (bandeira provavelmente defendida por oposição sindical ou minoria de diretoria); defesa dos direitos humanos; legalização do aborto; luta por moradia, em defesa do monopólio estatal do petróleo; passe livre para estudantes; reformas agrária e urbana; pelo socialismo e o apelo a uma prática política e organizativa classista.

Mesmo heterogêneas, as bandeiras da Conlutas podem ser aglutinadas em algumas categorias que dizem respeito aos direitos trabalhistas, às questões da educação, contra as políticas e ações neoliberais, em defesa de reformas rural e urbana, bem como questões relativas ao sindicalismo, à saúde, à mulher, à raça e ao meio ambiente. As questões que mais mobilizam as entidades dos delegados da Conlutas referem-se aos direitos trabalhistas e previdenciários (39,8\%), às questões relativas à educação $(16,6 \%)$ e contra as políticas e ações de natureza neoliberais - privatização, reforma trabalhista, reforma da previdência (12,2\%) (Tabela 24).

Quando consideradas as bandeiras de luta priorizadas por cada tipo de entidade, o resultado é relativamente esperado: os sindicatos privilegiam direitos trabalhistas e previdenciários, enquanto os movimentos sociais dividem-se conforme o perfil de sua organização. Entre os sindicatos do setor público, além das questões relativas aos direitos trabalhistas e previdenciários, destacam-se também questões relativas à educação, provavelmente em função da importante presença de professores na Conlutas. Os movimentos populares, estudantil e as outras entidades defendem bandeiras variadas, mas predominam as bandeiras relativas à educação (25,4\%), às bandeiras antineoliberais (20\%), à questão fundiária rural e urbana $(15,4 \%)$ e aos direitos trabalhistas e previdenciários (10\%). Os delegados representantes de entidades ligadas ao movimento estudantil, além da educação, defendem também bandeiras relativas a direitos trabalhistas e previdenciários, o que parece ser um indicativo de estratégia de aproximação das lutas dos trabalhadores. 
Tabela 24

Delegados por bandeira de luta da entidade e por tipo de entidade (\%)

\begin{tabular}{|c|c|c|c|c|c|}
\hline Bandeiras & $\begin{array}{l}\text { Sindicato do } \\
\text { Setor Público }\end{array}$ & $\begin{array}{l}\text { Sindicato de } \\
\text { Setor Privado }\end{array}$ & $\begin{array}{c}\text { Movimento popular, } \\
\text { estudantil e outra } \\
\text { entidade }\end{array}$ & $\begin{array}{l}\text { Total } \\
(\%)\end{array}$ & $\mathbf{N}$ \\
\hline $\begin{array}{l}\text { Direitos trabalhistas e } \\
\text { previdenciários }\end{array}$ & 55,0 & 71,7 & 10,0 & 39,8 & 127 \\
\hline $\begin{array}{l}\text { Questões relativas à } \\
\text { educação }\end{array}$ & 14,7 & 1,7 & 25,4 & 16,6 & 53 \\
\hline Antineoliberais & 7,0 & 6,7 & 20,0 & 12,2 & 39 \\
\hline $\begin{array}{l}\text { Questão fundiária rural e } \\
\text { urbana }\end{array}$ & . & . & 15,4 & 6,3 & 20 \\
\hline Socialista & 7,0 & 8,3 & 3,8 & 6,0 & 19 \\
\hline $\begin{array}{l}\text { Questões de organização e } \\
\text { mobilidade sindical }\end{array}$ & 6,2 & 1,7 & 3,1 & 4,1 & 13 \\
\hline $\begin{array}{l}\text { Questão de saúde e } \\
\text { proteção social }\end{array}$ & 1,6 & . & 2,3 & 1,6 & 5 \\
\hline Questões de raça/etnia & 0,8 & . & 2,3 & 1,3 & 4 \\
\hline Questões ambientais & - & . & 1,5 & 0,6 & 2 \\
\hline Questões de gênero & - & - & 2,3 & 0,9 & 3 \\
\hline $\begin{array}{l}\text { Questões de organização e } \\
\text { mobilidade estudantil }\end{array}$ & 0,8 & . & 2,3 & 1,3 & 4 \\
\hline Outras & 7,0 & 10,0 & 11,5 & 9,4 & 30 \\
\hline Total & 100 & 100 & 100 & 100 & $319 *$ \\
\hline
\end{tabular}

Fonte: Banco de Dados da Conlutas e Banco de dados das pesquisadoras.

\section{Considerações Finais}

O presente artigo constitui um primeiro esforço de análise sobre o perfil da Conlutas. Nosso principal objetivo foi apresentar dados inéditos sobre uma central sindical de oposição ao governo Lula. Acreditamos que a pesquisa evidenciou importantes características sobre as suas bases, mais especificamente sobre o perfil de seus delegados e de suas entidades. Nessas considerações finais priorizamos algumas observações sobre a composição social da central.

Sistematizando as informações colhidas, chegamos ao seguinte perfil: os delegados presentes no $1^{\circ}$ Congresso da Conlutas são brasileiros, majoritariamente homens, negros, residentes nas regiões sudeste e nordeste do Brasil; com nível de escolaridade superior (incompleto e completo); realizam trabalho não-manual; ocupam cargos de média hierarquia; encontram-se inseridos no setor público; trabalham no mesmo setor econômico e no mesmo emprego por um período relativamente extenso, dispõem de uma situação trabalhista caracterizada pela formalidade, pelo estabelecimento de contratos por tempo indeterminado, firmados diretamente com as empresas nas quais exercem sua atividade e que, finalmente, percebem uma renda mensal de até 3 salários mínimos.

Este perfil evidencia que a Conlutas agrega forças sociais predominantemente de classe média (SAES, 1985; BolTo, 2007). A classe média, contudo, é um conjunto muito heterogêneo: de um lado, tem-se a baixa classe média, composta por trabalhadores que, embora tenham uma condição 
salarial próxima ou até mesmo inferior à classe operária, em função de sua situação de trabalho (remuneração, proximidade com o público, certa autonomia na realização das tarefas) e de disposições ideológicas próprias, tendem a se opor e distinguir-se dos trabalhadores manuais (TRÓPIA, 1994). De outro lado, há os setores da alta classe média, cujo salário, tipo de trabalho e, sobretudo, apego à ideologia meritocrática (SAES, 1985; FANTINATTI, 1998) tendem a aproximá-los de posições políticas burguesas. Pois bem, segundo nossa pesquisa, na Conlutas predominam setores de classe média, especialmente ligados à educação, como o Sindicato dos Trabalhadores da USP (Sintusp) e os professores da rede pública estadual de São Paulo que fazem oposição à direção da Apeoesp. Há também setores que podem ser considerados como de alta classe média, tais como professores universitários filiados a sindicatos do Andes e trabalhadores do sistema judiciário - ambas camadas com rendimentos mensais superiores a 15 salários mínimos, as quais seriam fortemente marcadas pela ideologia meritocrática. Ademais, entre os delegados representantes dos movimentos sociais, encontrase o movimento estudantil, formado, sobretudo, por jovens oriundos das classes médias.

A Conlutas também é composta por vários setores populares, tais como o campesinato representado pelo Movimento Terra, Trabalho e Liberdade-DI e setores da classe operária representados por diversos sindicatos do setor industrial privado. A presença de todos esses setores em uma central de esquerda, hegemonizada por um partido autodenominado socialista e operário de pouca expressão no cenário político nacional (PSTU), permite afirmar que se trata de uma ampla frente política. Segundo as hipóteses que levantamos, todos são setores que tiveram perdas expressivas com as políticas neoliberais de precarização das condições de trabalho e emprego, arrocho salarial, reforma da previdência, bem como com o apoio dado pelo governo Lula ao grande capital agroexportador - em detrimento da agricultura familiar.

Nossa pesquisa fornece o material inicial necessário para aprofundar algumas questões interessantes sobre a composição social da Conlutas, sua origem e suas bandeiras de luta. Encerramos nosso artigo com algumas delas:

1. A predominância de trabalhadores não-manuais, entre eles servidores públicos dos setores de educação e cultura, está relacionada à origem da Conlutas e suas bandeiras. Foi entre os trabalhadores com este perfil que ela construiu suas fileiras. Mas, além da questão propriamente conjuntural, haveria outras razões para sindicatos de classe média apoiarem uma central auto. denominada socialista e operária? Que razões seriam essas?

2. A bandeira mais geral que unificou a Conlutas em sua origem, a luta contra as reformas do governo Lula, uma bandeira conjuntural, pode continuar cimentando e atraindo novas bases? Ou ainda, esse fator conjuntural pode continuar funcionando para unificar setores tão diversos? Ou as bandeiras que unificaram setores tão variados tendem a perder importância com as mudanças na conjuntura política e social?

3. Nossa pesquisa mostra que existe dentro da Conlutas um paradoxo entre o discurso contra a unicidade sindical e as contribuições sindicais compulsórias, de um lado, e a importante incidência de sindicalistas que apoiam a estrutural sindical oficial, de outro. Esse paradoxo também se 
reflete na crítica à estrutura feita de maneira genérica e na tática de disputar os sindicatos "por dentro", para "não dividir o movimento". O que esse paradoxo significa para a constituição da central? O não enfrentamento da estrutura sindical oficial representa ou não um limite para o crescimento e atuação de uma central de esquerda?

4. É necessário também ampliar a discussão sobre a natureza de classe predominante na Conlutas: que programa socialista pode construir uma central que agrega, predominantemente, o que podemos denominar de trabalhadores de classe média?

5. Quais são as consequências, para o movimento sindical presente dentro da Conlutas, da participação de organizações de movimento popular e estudantil nas decisões tomadas pela central?

6. A constituição da Conlutas poderia ser caracterizada como mais um indício do processo de revigoramento do sindicalismo no Brasil na década de 2000 (BOITO e MARCELINO, 2010)?

Essas são algumas das questões que o conjunto de dados aqui apresentados permite formular e que nos estimulam a prosseguir trabalhando.

\section{Referências Bibliográficas}

Boıto, A. Classe média e sindicalismo. Estado, Política e Classes Sociais. São Paulo: Editora UNESP, 2007.

e MARCelino, P. R. P. "O sindicalismo deixou a crise para trás? Um novo ciclo de greves na década de 2000". Cadernos do CRH, vol. 23, n 59, p. 323.338, 2010.

CARvalho, G. Relatório sobre o X CONCUT, mimeo, 2009.

CONLUTAS. Coordenação pretende se construir como uma alternativa de luta para os trabalhadores [online]. Conlutas, 2004. Disponível em: <www.conlutas.org.br>. Acesso em: 05 out. 2006

Resoluções do Congresso Nacional dos Trabalhadores, 2006.

Fantinattı, M. Sindicalismo de Classe Média e Meritocracia: o movimento docente na Universidade Pública. Campinas, 239 p. Dissertação de Mestrado em Sociologia. Unicamp, Instituto de Filosofia e Ciências Humanas, 1998.

ForÇa Sindical. Revista da Força, Ano 18, 2009.

Galvão, A. "O movimento sindical frente ao governo Lula: dilemas, desafios e paradoxos". Revista Outubro. Revista do Instituto de Estudos Socialistas, n¹4, p. 131-150, 2006.

. Neoliberalismo e reforma trabalhista no Brasil. São Paulo: Revan, 2007.

"A reconfiguração do movimento sindical no governo Lula". Revista Outubro, n 18, p. 175-197, 2009.

INTERSINDICAL. Manifesto: Intersindical, um instrumento a serviço da luta de classes [online]. Intersindical, 2006. Disponível em: <http://acaopopularsocialist.locaweb.com.br/textos/manifesto-intersindical-2006.pdf>. Acesso em: 10 nov. 2006.

JÁCOME RODRIGUES, I. Sindicalismo e política: a trajetória da CUT. Scritta: São Paulo, 1997.

Rodrigues, L. M. CUT: os militantes e a ideologia. Rio de Janeiro: Paz e Terra, 1990.

e CARdoso, A. M. Força Sindical - uma análise sócio-política. Rio de Janeiro: Paz e Terra, 1993.

SAES, D. "Classe média e política de classe. Uma nota teórica". Contraponto. Rio de Janeiro: Centro de Estudos Noel Nutels, n², p. 96-102, 1978. 
TRÓPIA, P. V.; GALVÃO, A.; MARCELINO, P. A reconfiguração do sindicalismo:... Classe média e sistema político no Brasil. São Paulo: T.A. Queiroz, 1985.

TRÓPIA, P. Classe média, situação de trabalho e comportamento sindical: o caso dos comerciários de São Paulo. Campinas, 187 p. Dissertação de Mestrado em Ciência Política. Unicamp, Instituto de Filosofia e Ciências Humanas, 1994.

A Força Sindical diante do Governo Lula. Anais do VII Seminário do Trabalho - Trabalho, educação, sociabilidade, Marília, 2010.

Patrícia Vieira Trópia - tropia@uol.com.br

Andréia Galvão - agalvao@unicamp.br

Paula Marcelino - prpmarcelino@gmail.com

Submetido à publicação em março de 2012.

Versão final aprovada em abril de 2013. 